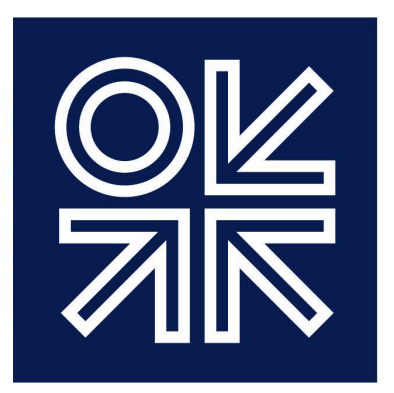

THE OXFORD

INSTITUTE

FOR ENERGY

STUDIES

October 2014

\title{
Challenges across Brazil's oil sector and prospects for future production
}

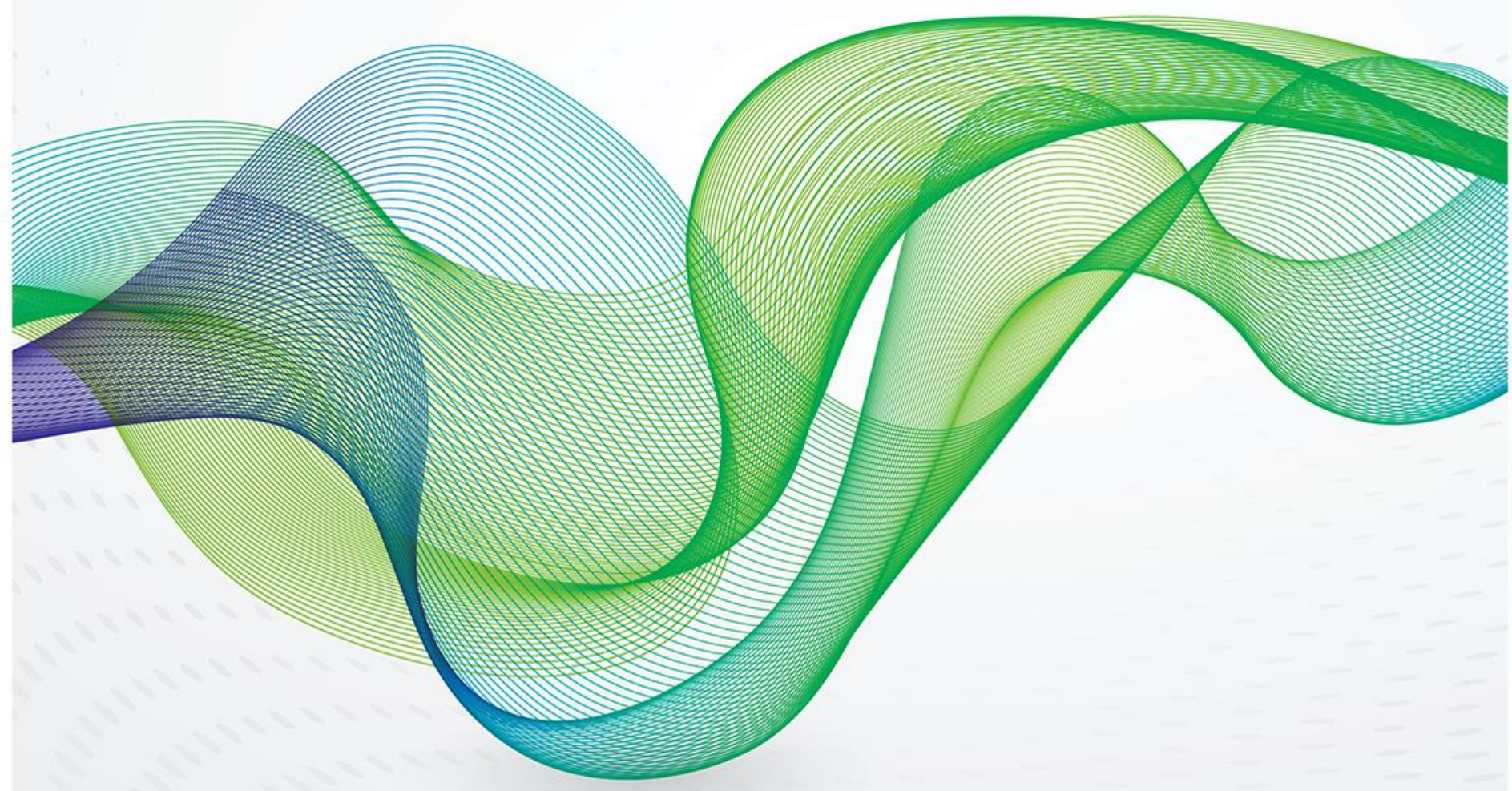


The contents of this paper are the authors' sole responsibility. They do not necessarily represent the views of the Oxford Institute for Energy Studies or any of its members.

\section{Copyright (C) 2014}

\section{Oxford Institute for Energy Studies}

(Registered Charity, No. 286084)

This publication may be reproduced in part for educational or non-profit purposes without special permission from the copyright holder, provided acknowledgment of the source is made. No use of this publication may be made for resale or for any other commercial purpose whatsoever without prior permission in writing from the Oxford Institute for Energy Studies.

ISBN 978-1-78467-013-9

* Virendra Chauhan is an oil analyst at Energy Aspects

** Maarten van Mourik is an independent oil market analyst

*** Pedro Florencio is a is a member of the Brazilian Senior Executive Service and a Ph.D candidate at the University of Warwick with a thesis focussed on the Brazilian Oil sector 


\section{Abstract}

After signs of early promise following the discovery of large reserves in Brazilian pre-salt basins in 2007 and 2008, several issues have impacted the pace of project development, culminating in output declining year-on-year in 2012 and 2013. This paper examines the key challenges facing Brazil's oil sector, which include: rising domestic demand, which has impacted Petrobras' finances; high decline rates in mature basins; cost escalation in both the upstream and downstream sectors; and changes in the regulatory framework, which reduced the attractiveness of the new finds and deterred foreign investment. These factors resulted in Petrobras missing its production target for eight consecutive years, in addition to a $1 \mathrm{mb} / \mathrm{d}$ reduction along its future oil production curve estimates. 


\section{Contents}

Abstract.

I. Introduction ii

II. The Brazilian oil sector: supply, demand, and trade...

Reserves and Production

Domestic Demand

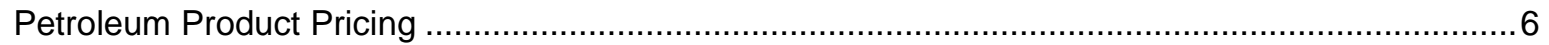

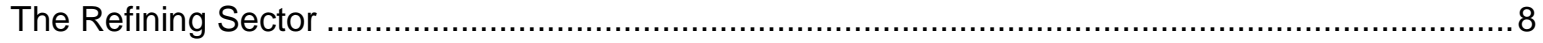

Crude Oil and Product Trade Flows ................................................................................ 10

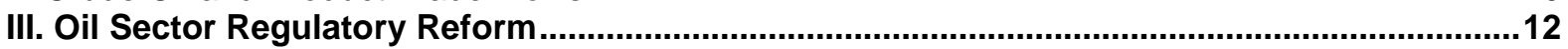

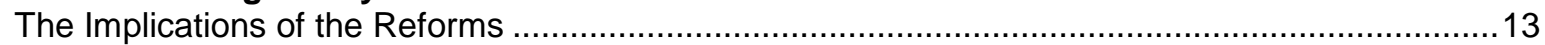

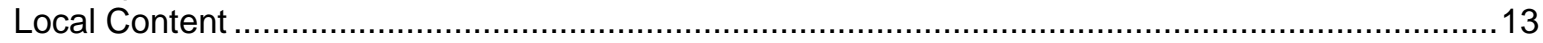

Lack of Adjustment in Prices for the Local Market........................................................................ 14

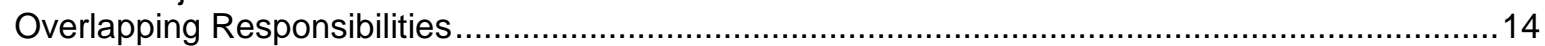

IV. Other Challenges: High Decline Rates and Cost Escalation ...............................................16

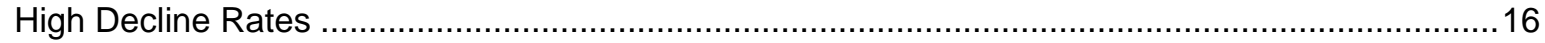

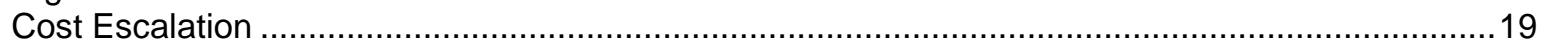

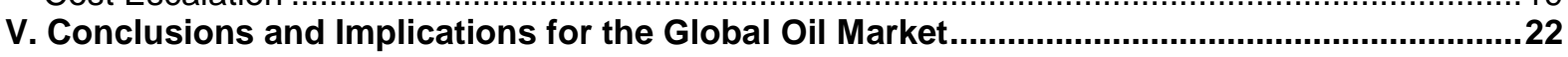

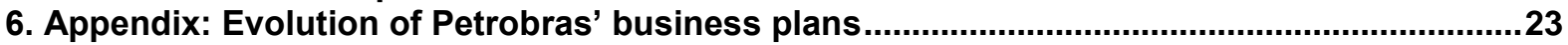

\section{Figures}

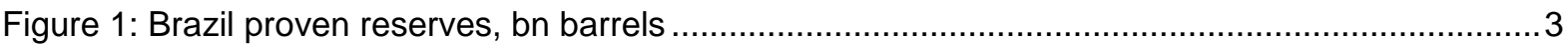

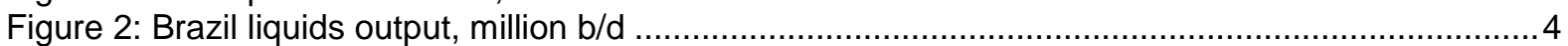

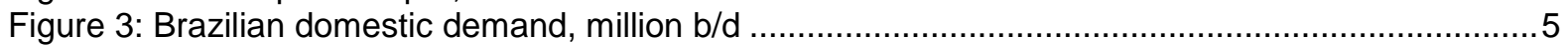

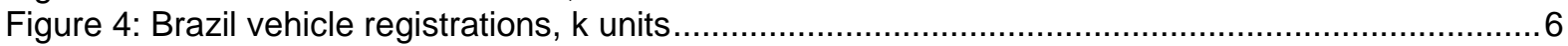

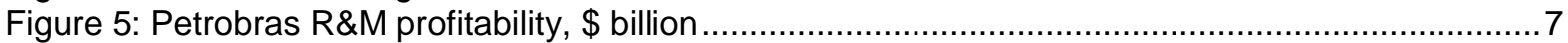

Figure 6: Domestic vs. International Product Prices, $\$$ /Barrel ..................................................... 8

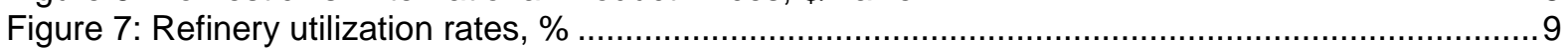

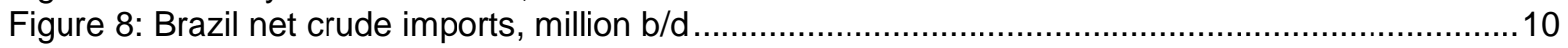

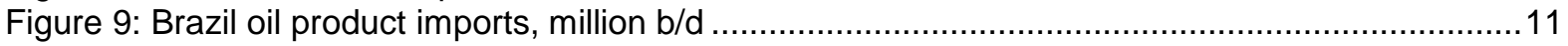

Figure 10: Brazil's offshore production by field vintage, million b/d ............................................... 17

Figure 11: Brazil's deepwater production by well vintage, million b/d .......................................18

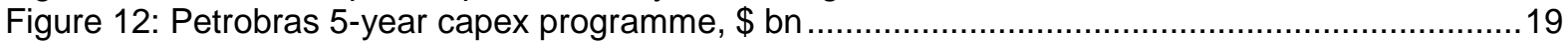

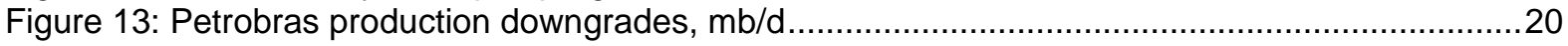

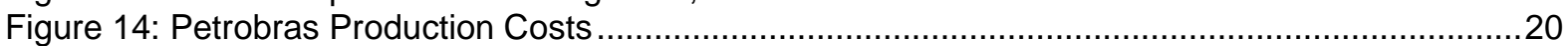



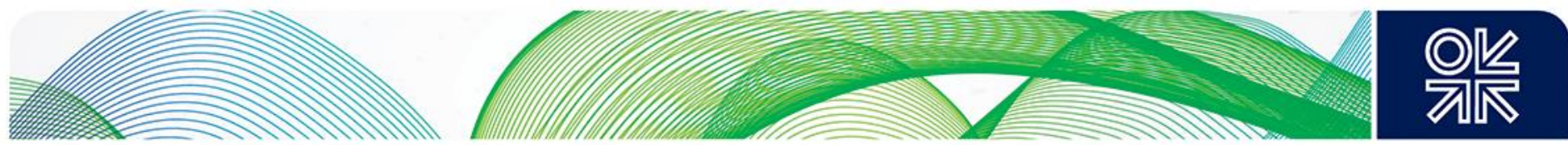

\section{Introduction}

Less than 10 years ago, at the height of the commodities boom, Brazil was all but assured a place as an oil world powerhouse following the discovery of oil in its subsalt basins. Much faith has been put in Brazil delivering the barrels needed to keep the medium-term oil market in reasonable balance. Whether it is the IEA ${ }^{1}, \mathrm{EIA}^{2}, \mathrm{OPEC}^{3}$, major oil companies, or indeed the Brazilian government, all projected the country's oil production to increase substantially in the coming years. This optimism was brought to the forefront of the global oil and gas industries by the 2007/2008 discovery of the vast pre-salt basins, specifically the Tupi field. ${ }^{4}$ This ranks alongside Kashagan ${ }^{5}$ as one of the largest and most significant oil discoveries of the past few decades and the biggest in the Americas since the Cantarell field in Mexico in 1976. ${ }^{6}$ However, as has often been the case in recent history for the oil markets, a number of project delays and cost overruns have since taken the shine off the initial optimism, and has also kept Brazil from playing a bigger role in the non-OPEC supply picture.

State-owned operator Petrobras accounts for over 90 per cent of Brazil's production and has been at the centre of development in the country's oil sector. Petrobras has registered a reserve replacement ratio above 100 per cent for each of the past 22 years, ${ }^{7}$ with the 2013 figure at an impressive 135 per cent. This comes at a time when other major oil companies have been struggling to add incremental reserves to their portfolios. Despite the addition to reserves, Petrobras missed its annual production target in the period between 2003 and 2011 , and even saw its annual output decline over the past two years, falling 2 per cent in 2012 and 1.6 per cent in 2013. ${ }^{8}$

So what has slowed the progress in the Brazilian oil sector? We argue that Brazil's upstream sector faces a number of key challenges, including: regulatory barriers; a massive financial burden, consisting of the world's largest corporate expenditure programme amassing $\$ 220.6$ billion ${ }^{9}$ and increasingly funded by debt; high production costs and high decline rates; caps on domestic fuel prices, which have adversely affected Petrobras' earnings; and waning interest from major international oil companies (IOCs) in co-financing projects. The country's deepsea bonanza has become less alluring, whilst oil companies have also been adapting to a changing energy landscape, altered by a focus on capital discipline, shale in the US, and the emergence of other frontier energy sources, such as in deepwater Africa or oil sands in Canada.

\footnotetext{
IEA July Oil Market Report, "Brazil stands out as the largest source of growth in the 2015 forecast (after the US and Canada)..."

${ }^{2}$ EIA Country Analysis brief-Brazil, http://www.eia.gov/countries/analysisbriefs/brazil/brazil.pdf, accessed 13 May $\underline{\underline{2014}}$

${ }^{3}$ OPEC MOMR, September 2014.

4 'Tests confirm discovery of light oil in the Santos Basin', Petrobras, 20 Sep 2007,

http://www.investidorpetrobras.com.br/pt/comunicados-e-fatos-relevantes/testes-confirmam-descoberta-de-oleo-levena-bacia-de-santos.htm, accessed 18 May 2014

5 '5 Of The Biggest Oil Finds In History', Commodity HQ, 7 December 2012, http://commodityhq.com/2012/5-of-thebiggest-oil-finds-in-historyl, accessed 14 May 2014

6 ‘Brazil's Libra Discovery May Hold 8 Billion Barrels of Oil, Rivaling Tupi,' Bloomberg, 13 September 2010, http://www.bloomberg.com/news/2010-09-13/brazil-s-offshore-libra-field-may-hold-8-billion-barrels-rivaling-tupi.html/, accessed 14 May 2014

${ }^{7}$ Author, '2013 Net Income', Petrobras magazine, 2012, http://www.petrobras.com/en/magazine/post/2013-netincome-of-r-23-57-billion.htm/, accessed 19 May 2014

${ }^{8}$ ANP statistics available at http://www.anp.gov.br, accessed 19 May 2014

${ }_{9}^{9}$ Petrobras 2014-2018 Investment plan.
}

October 2014 - October 2014 - Challenges across Brazil's oil sector and prospects for future production 

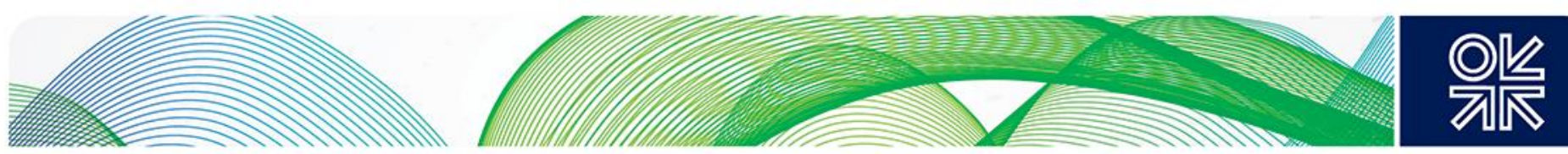

The paper is divided into four main sections. Section 2 considers the key components making up Brazil's upstream, looking at reserves from a historic perspective and how these have been developed for the better part of a decade before hitting a stumbling block in 2012. This section also looks at the three key basins that produce the majority of Brazil's 2 million b/d of output. Section 2 also considers the impact of subsidies, both from a historic and present day perspective, and discusses the implications of domestic demand on trade patterns for both crude oil and oil products. Section 3 discusses the changes in the regulatory framework and its implications across the Brazilian upstream sector, with a particular emphasis on how such changes have impacted developments across the oil sector as the scale and potential of the pre-salt became apparent. Sections 4 focuses on the challenges which Brazil has faced over the past three years, with a particular focus on rising costs and steep decline rates associated with its deepwater production. The last section draws some conclusion and looks at the broader implications of production growth/decline in non-OPEC supplies. 

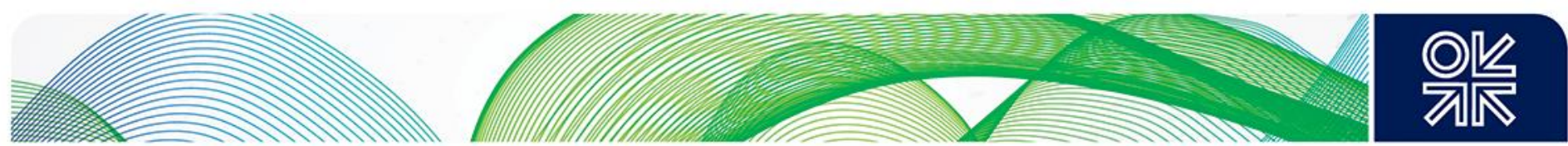

\section{The Brazilian oil sector: supply, demand, and trade}

Brazil's oil sector has witnessed some fundamental transformations in the last few years. These range from the discovery of huge reserves and the challenge of translating them into higher production, to developments on the demand side and refining, which affected the country's crude oil and petroleum product trade flows and its energy links with the rest of the world.

\section{Reserves and Production}

Brazil's proved oil reserves have been increasing since the turn of the millennium (particularly in the second half of the 2000s), with the 2014 edition of BP's Statistical Review of World Energy placing the country's reserves at 15.6 billion barrels - some 0.9 per cent of the world's oil proven reserves. Today, it boasts the second largest reserves in Latin America (which holds 19.5 per cent of global oil proven reserves), and if the projection holds, the Libra field could almost double the country's reserves from 2012 levels. ${ }^{10}$ According to Petrobras, this stands as the largest oil reserve ever discovered in Brazil, with probable reserves estimated at just under 8 billion barrels. ${ }^{10}$

Figure 1: Brazil proven reserves, bn barrels

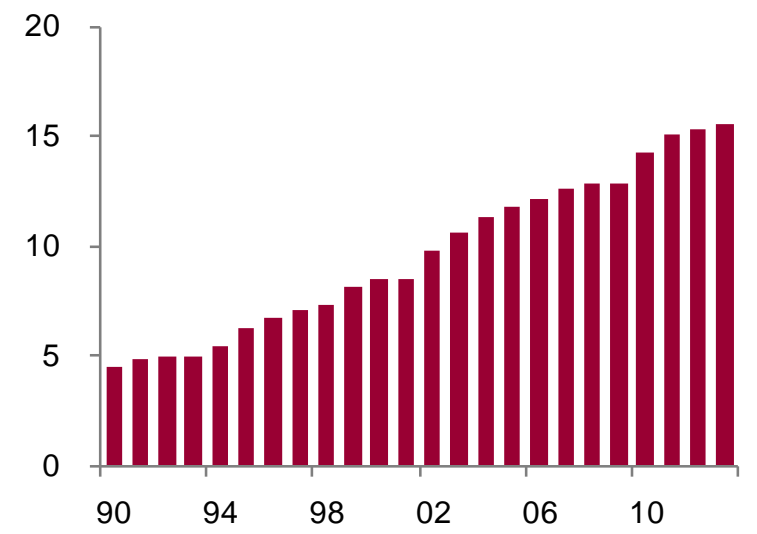

Source: BP, Statistical Review of World Energy 2014

From 2000 to 2011, Brazilian oil production registered year-on-year growth in 10 out of 11 years at an average rate of nearly 0.1 million b/d, rising from 1.23 million b/d in 2000 to 2.11 million b/d in 2011 (see Fig 2). However, 2012 and 2013 saw an abrupt reversal, with production registering year-on-year declines by 44 thousand b/d and 35 thousand $b / d$ respectively. In the year to July 2014 , production has increased to 2.16 million b/d, higher year-on-year by 0.17 million b/d. ${ }^{11}$ This recent surge has been supported both by a low base and by new floating production storage offloading (FPSO) vessels coming online, which have allowed pre-salt production to reach a record high of over 0.5 million b/d. Efficiency gains from a period of heavy maintenance and investment are also starting to bear fruit.

\footnotetext{
${ }^{0}$ Deep future', Petrobras magazine, http://www.petrobras.com/en/magazine/post/deep-future.htm, accessed 21 May $\underline{2014}$

${ }^{11}$ Author analysis of production data published by ANP.
} 

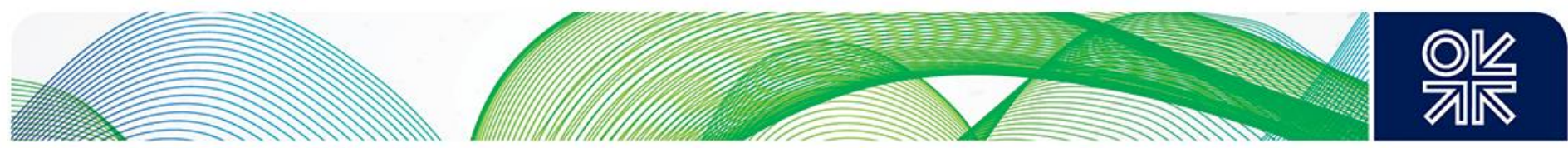

Figure 2: Brazil liquids output, million b/d

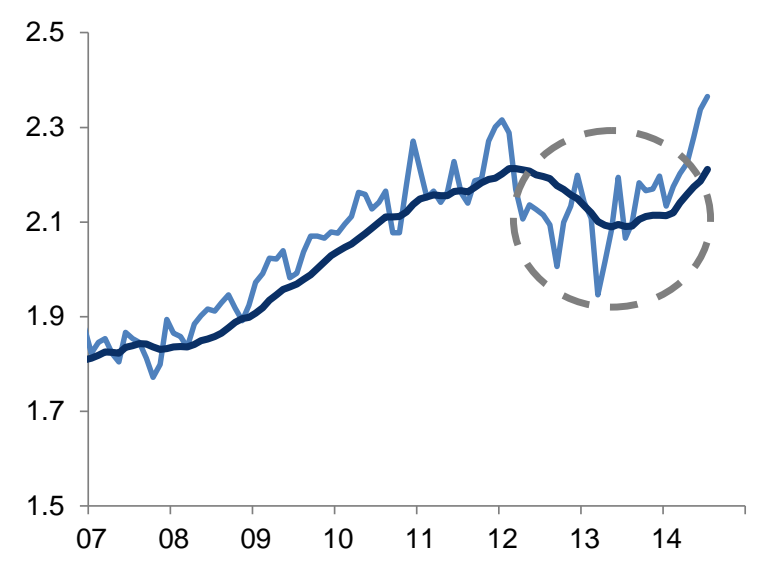

Source: ANP

Brazil's production originates from three main producing basins. The Campos Basin covers approximately 115 thousand square kilometres and is the most prolific basin in Brazil as measured by proved reserves (72 per cent) and production. ${ }^{12}$ In 2013, 75 per cent of oil production ( 1.53 million b/d) was produced from 47 fields in this basin. Since exploration began in 1971, over 60 hydrocarbon accumulations have been discovered, including eight large deepwater and ultra-deepwater oil fields. ${ }^{13}$ Most production in the Campos Basin originates from the post-salt reservoirs, although going forward, pre-salt reservoirs will become increasingly important. Pre-salt production began in 2008 from the Jubarte field located in the Parque das Baleias region. ${ }^{14}$ Thereafter, production began at the Baleia Franca field in the second half of 2010, followed by the Baleia Azul region using the FPSO 'Cidade de Anchieta' in September 2012. At the end of 2013, pre-salt production in the Campos Basin reached 0.17 million b/d and whilst a split is not available for 2014 , anecdotal evidence suggests that the first half of the year has seen an acceleration in well activity and therefore output. ${ }^{15}$

The Santos Basin is the second of the three main basins, covering approximately 348,900 square kilometres off the coast of the city of Santos, which is one of the most promising exploration and production (E\&P) areas offshore Brazil according to Petrobras. The pre-salt has been a central focus of E\&P activities with 13 of the 15 wells being drilled in that region in 2013. Several discoveries have been made in the pre-salt reservoirs of the Santos Basin in recent times, whilst the development of previous discoveries (such as Tupi) have allowed Santos Basin output to rise steadily over $2013 .{ }^{16}$ Output increased from 0.11 million b/d in January 2013 to 0.28 million b/d by year-end as five out of nine production units produced first oil during the year. ${ }^{17}$ Output averaged 0.19 million b/d in 2013, higher year-on-year by 80 thousand b/d. The steady growth trend has continued and by July 2014 pre-salt production (Santos and Campos) reached 0.55 million $\mathrm{b} / \mathrm{d}$. That this was accomplished eight years after the first pre-salt discovery in 2006, and achieved from around 30 wells, highlights the high productivity of pre-salt fields. Petrobras has set a target of achieving more than 1 million b/d

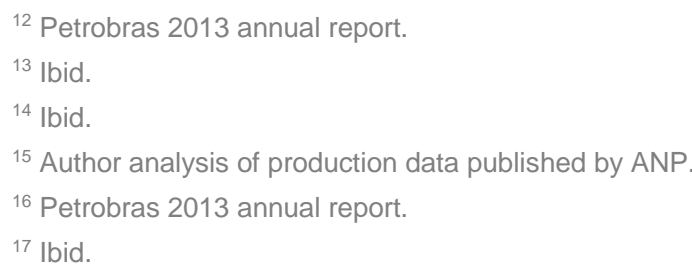



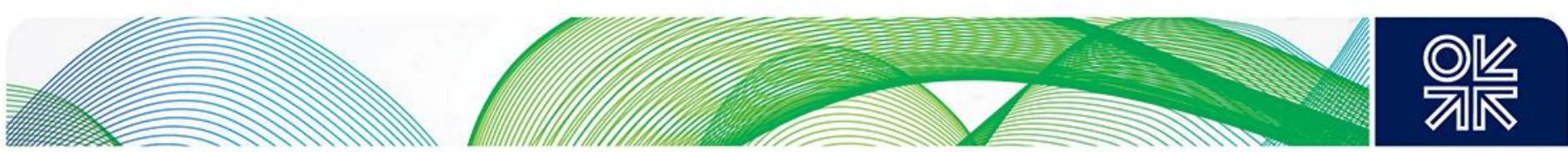

of output from pre-salt by 2017 in the fields they operate. ${ }^{18}$ Future production from the Santos Basin will be predominantly from deep and ultra-deepwater fields with 13 major projects in the development pipeline.

The third of the larger basins is the Espirito Santo Basin, covering an area of 75 thousand square kilometres offshore and 14 thousand square kilometres onshore. At the end of 2013 there were 45 producing fields at an average rate of 49 thousand $\mathrm{b} / \mathrm{d}$. ${ }^{19}$ The main characteristic of the field is believed to be the diversity of resources, with output varying from gas to extra-heavy oil.

Finally, there are several smaller basins, including the Sergipe-Alagoas Basin, a new frontier offshore region, where production was around 47 thousand b/d in $2013 .{ }^{20} 20$ other basins produce hydrocarbons in Brazil. Onshore production stems primarily from mature fields, and so development plans are largely focused on sustaining output levels using enhanced recovery methods. In 2013, these basins produced 0.17 million b/d of oil. ${ }^{21}$

\section{Domestic Demand}

Whilst production has been on an impressive growth trajectory over the past 14 years, domestic consumption of oil and oil products has seen an equally, if not more impressive growth trend. Brazil's growth story was very much underpinned by the 2000-2010 commodities boom, and has been amongst the darlings of the emerging markets. The 2008 financial crisis was the inflection point at which oil demand started its steady march towards the 2.5 million b/d levels seen today. ${ }^{22}$ Since 2000, Brazilian oil demand has risen by almost 1 million $\mathrm{b} / \mathrm{d}$, although the impressive pickup has been concentrated in the last seven to eight years: ${ }^{23}$ up from 1.4 million b/d in January 2006 to a peak of just under 2.5 million b/d in late 2013. The sharp increase has put pressure on the country's ageing domestic refineries, which have seen utilization rates rise steadily to near capacity levels.

Figure 3: Brazilian domestic demand, million b/d

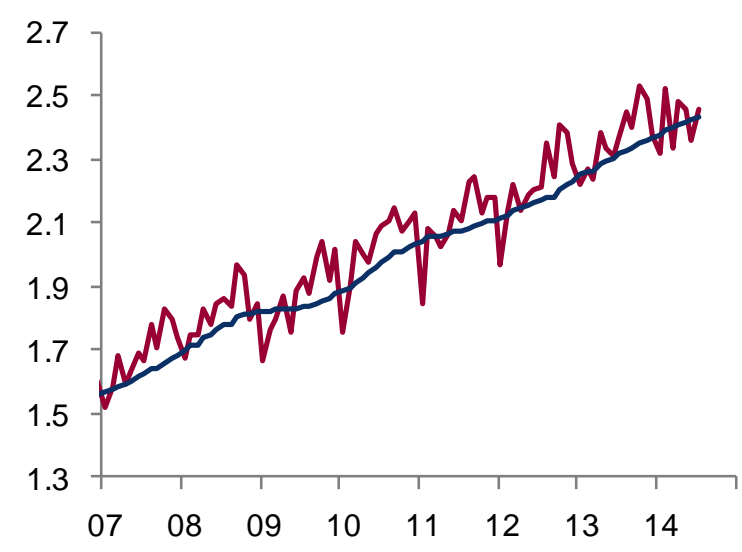

Source: ANP

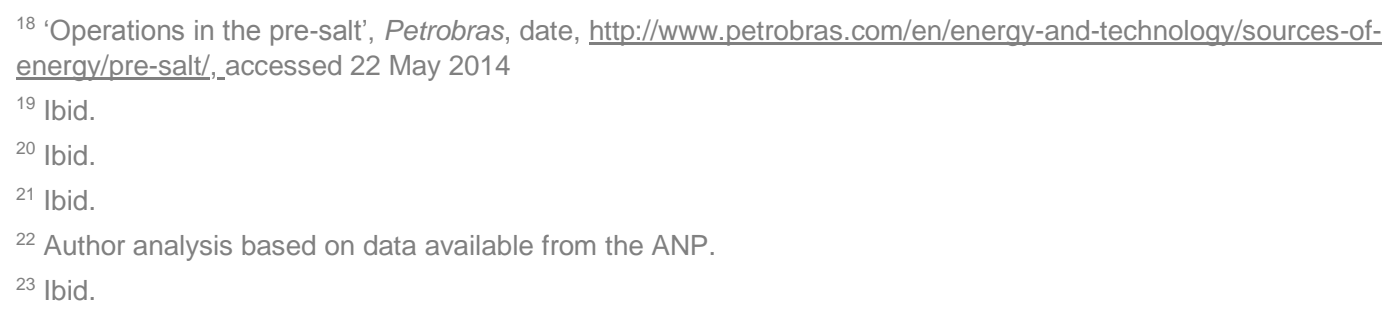



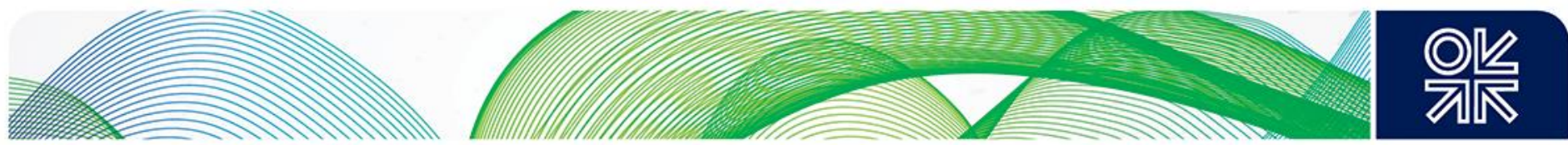

Over the past two years, a weakening Brazilian currency and slower growth across emerging markets has stoked fears of slower oil demand growth. However, as Fattouh, Sen, and Sen argue (2012) for other emerging markets such as India, ${ }^{24}$ oil demand growth is fairly inelastic and Brazil is very similar. GDP growth has eased from the lofty 7.5 per cent seen in 2010 to 2.3 per cent in 2013 and yet oil demand has risen steadily at a rate of 5 per cent per annum. ${ }^{25}$ Part of the growth in demand clearly relates to the subsidies, ${ }^{26}$ but in general income elasticity tends to dominate price elasticity in emerging nations.

Beyond near-term growth concerns, government incentives have also been fundamental in boosting Brazilian oil demand. Between 2002 and 2012 the average annual growth rate in auto sales was over 10 per cent, and the sector only showed signs of reversing last year. ${ }^{27}$ As a result, Brazil's new vehicle sales industry ranks as the world's fourth largest. The Workers' Party of presidents Lula and Rousseff relied on carmakers to stimulate the economy and maintain low unemployment levels as a barrage of incentives persuaded a burgeoning middle class to buy their first car. However, in line with the weakening economy, the incentives started to ease last year as rising defaults prompted banks to restrict car loans.

Figure 4: Brazil vehicle registrations, $k$ units

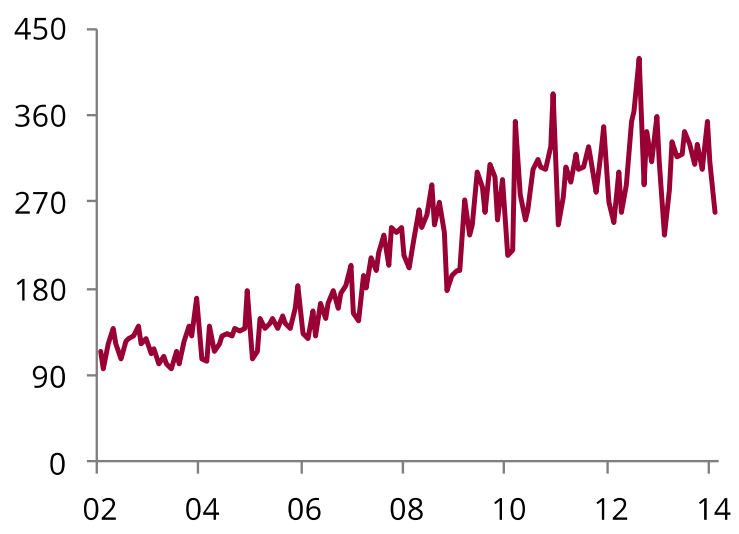

Source: Anfavea

In summary, despite the recent weakness in the domestic economy, Brazilian oil product demand is expected to continue on its growth path. This was echoed in Petrobras' medium and long-term outlook - estimated at 2.5 per cent for the period $2014-2018^{28}$ and 2.2 per cent for the period 2019-2030. ${ }^{29}$

\section{Petroleum Product Pricing}

The evolution, or rather lack thereof, in the downstream sector and the pricing of petroleum products has also played a key role in Brazil's oil industry. Economic performance in the pre-

\footnotetext{
${ }^{24}$ Bassam Fattouh and Amrita Sen, 'Diesel pricing reforms in India - a perspective on demand', Oxford Energy Forum, August 2013.

${ }^{25}$ Author analysis of production data published by ANP.

${ }^{26}$ It is worth noting that in the case of Brazil, part of the subsidies are implicit and does not involve the transfer of government funds to Petrobras. They represent the opportunity cost of not selling petroleum products at international prices. In addition to implicit subsidies, Petrobras incur losses by buying products at international prices and selling them to the local market at a lower price.

27 'Brazil's car sales hit reverse gear for first time in a decade', The Financial Times, 7 January 2014, http://www.ft.com/cms/s/0/005da614-77c2-11e3-807e-00144feabdc0.htm|\#axzz3DHleA3lh accessed 25 June 2014

${ }^{28}$ Petrobras 2014-2018 Investment plan.

${ }^{29} \mathrm{lbid}$.
}

October 2014 - October 2014 - Challenges across Brazil's oil sector and prospects for future production 

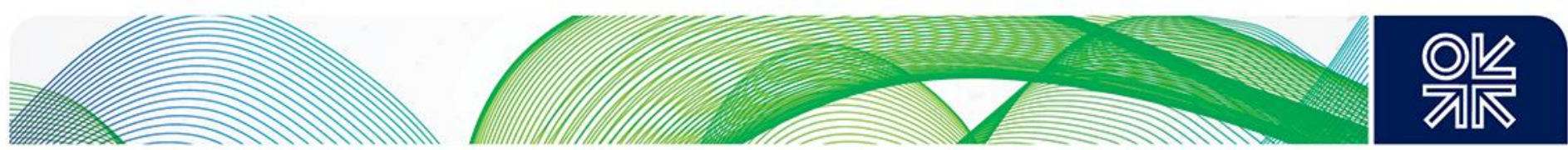

reform era of the 1980s was characterized by low growth, high inflation, and large fiscal imbalances. Economic growth during the period averaged 3 per cent whilst inflation averaged 272 per cent. ${ }^{30}$ Fiscal policy was expansionary, with the overall budget deficit averaging 5 per cent of GDP during the period. Meanwhile, debt increased from 24 per cent of GDP to 40 per cent of GDP in 1989, which pressured the authorities into liberalizing the economy, including the energy sector. ${ }^{31}$ An oil stabilization fund was established in 1980 to limit the effect of crude price volatility. Using this mechanism, oil sold to refineries was adjusted to keep oil costs for Petrobras' refineries at a set price determined by the government. The fund would accumulate contingent liabilities to Petrobras when international crude prices were high and would be offset in a low price environment. Rising oil import costs led to the fund and Petrobras running up large deficits. To help pay for the accumulated losses, the government transferred $\mathrm{R} \$ 5.8$ billion (0.8 per cent of GDP) to Petrobras in the mid-1990s. ${ }^{3230}$

Due to opposition from interest groups, a gradual approach was taken to the removal of subsidies in order to build public support for the reforms. A promise was made to consumers that privatization and liberalization would lower energy prices in addition to improving services. The actual liberalization process occurred in several stages with those products used by firms; for example asphalt and lubricants were first to see price rises, followed by gasoline (1996), LPG (1998), and diesel (2001). The first products to lose subsidies were those consumed by politically weak stakeholders, whilst those for use in transport and industry were removed later. The removal of subsidies for ethanol producers and suppliers of equipment and services to Petrobras was left to the end of the programme.

The dynamic effect of liberalizing oil product prices was a short-term spike in inflation, which smoothed out over the long term as prices were allowed to move in tandem with international markets; and this remains the concern today. Officially, oil prices are determined by Petrobras, though in practice the government uses them as a tool to control inflation. For example, the government has removed taxes on LPG and fuel oil to keep petroleum prices constant for the end consumer. ${ }^{33} \mathrm{~A}$ consequence of the lower levy rate has been that the aggregate tax amount has not increased in the face of growing consumption, resulting in operational losses for Petrobras' refining, marketing, and transportation business.

Figure 5: Petrobras R\&M profitability, \$ billion

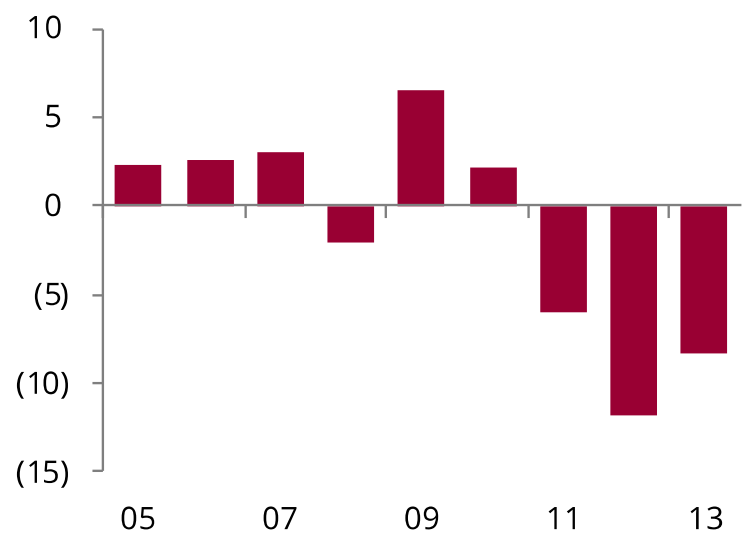

Source: Petrobras

\footnotetext{
30 'Case study on energy subsidy reforms: lessons and implications', International Monetary Fund, Washington, January 2014

${ }^{31}$ Author analysis based on data available from the ANP

32 Ibid.

${ }^{33}$ Carolina Santos de Oliveira and Bassam Fattouh, 'Gasoline and diesel pricing in BRIC countries: key issues and prospects of reform', The Oxford Institute for Energy Studies, accessed 7 July 2014
} 

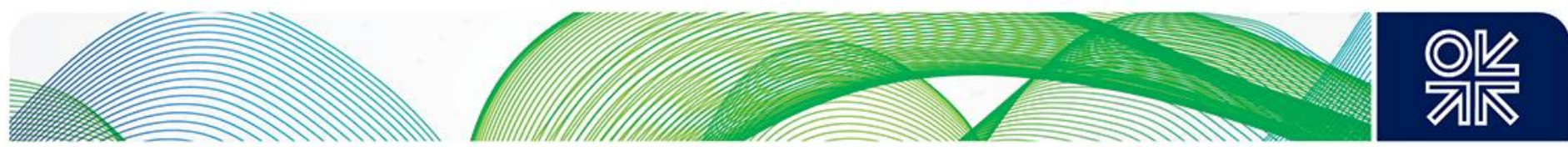

1995 saw the formal revoking of Petrobras' monopoly on upstream, refining, and trade of oil. In 1997 the Agencia National do Petroleo (ANP) was tasked with deregulating and restructuring the sector and managing the auctioning of oil fields for exploration. However, despite the wide-ranging scope of the authorities' privatization efforts, Petrobras has had an effective monopoly on the refining segment.

An official price liberalization for all fuel products has been in place in Brazil since 2002, and domestic fuel prices had been hovering above international levels despite significant pressure on the currency between 2001 and 2003. Fuel prices rose steadily until 2005, after which they levelled off despite fluctuations in international markets. The issue is that there is no official government price setting mechanism and under the ANP prices are simply monitored through 'surveys of fuel prices and margins'.

The downstream has been the biggest financial concern for Petrobras over the past three years. 2011 was the big turning point, when the government decided to subsidize fuel prices thus spurring domestic demand growth further and resulting in Petrobras having to import products such as gasoline and diesel at international prices. After three years with cumulative losses of $\$ 26$ billion, the company recognized that this was unsustainable and in November 2012 the board authorized the first fuel price increase in nine months, although it did not divulge the formula by which future prices would be adjusted. This left huge question marks over the proposed changes. With general elections to be held in October 2014, any price increases are going to be met with scepticism - as the protests in 2013 illustrated.

Figure 6: Domestic vs. International Product Prices, $\$$ /Barrel

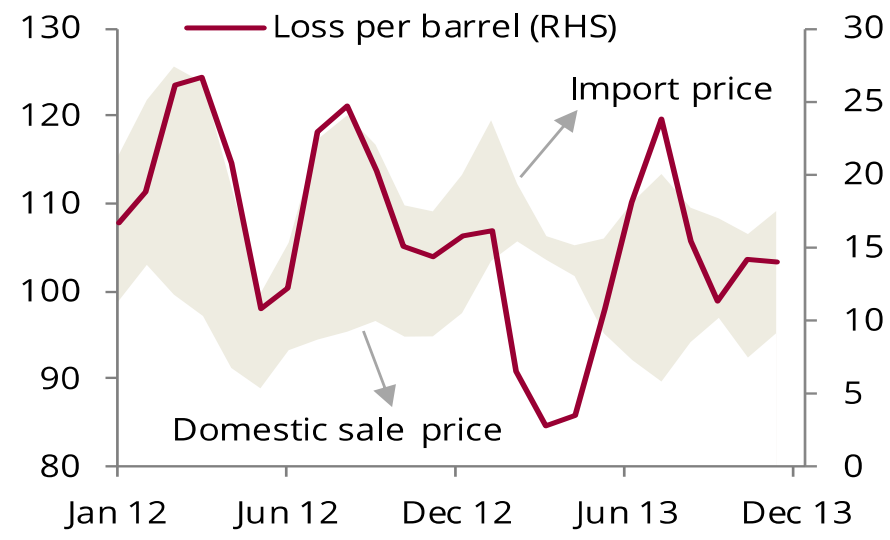

Source: Petrobras 2014-2018 plan, Energy Aspects

\section{The Refining Sector}

Whilst the state regulator ANP has indicated that Brazil may be able to ease its import burden by building new refineries, these are costly, time-intensive projects that have struggled to keep up with demand growth. Indeed, the Abreu e Lima refinery, which will have a processing capacity of 0.23 million $\mathrm{b} / \mathrm{d}$, is three years behind schedule and costs have ballooned to more than $\$ 20$ billion from an original budget of $\$ 2.3$ billion. ${ }^{34}$ Meanwhile, the 0.15 million b/d Comperj refinery is set to cost $\$ 13.6$ billion by the time it opens in late 2016 , four years later than originally planned and with cost overruns pegged at more than 60 per cent. ${ }^{35} \mathrm{As}$ a result Brazil has had to run its domestic refineries at nearly full capacity, which has still not been sufficient to satisfy domestic demand (see Fig 5), and the more Petrobras spends covering

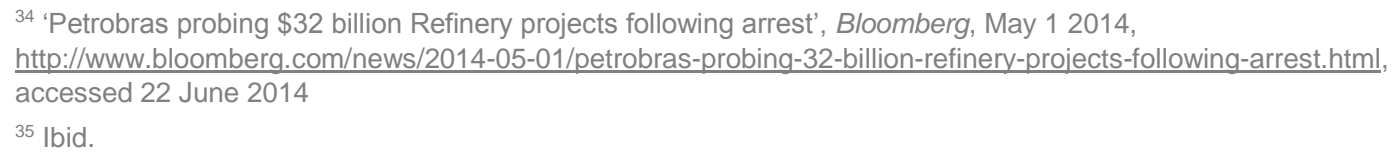

October 2014 - October 2014 - Challenges across Brazil's oil sector and prospects for future production 

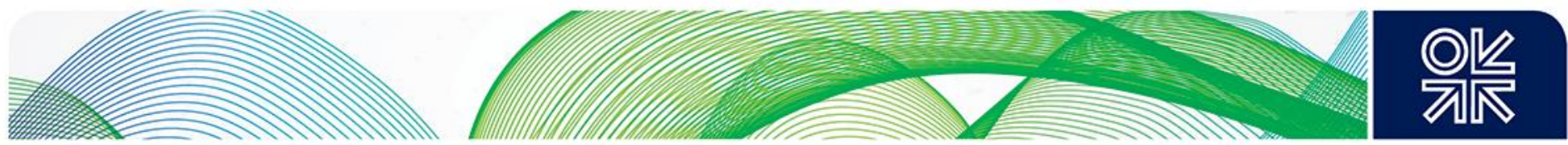

the gap between imported and domestic fuel pricing, the harder it becomes for the company to finance any acceleration of refinery projects.

Figure 7: Refinery utilization rates, $\%$

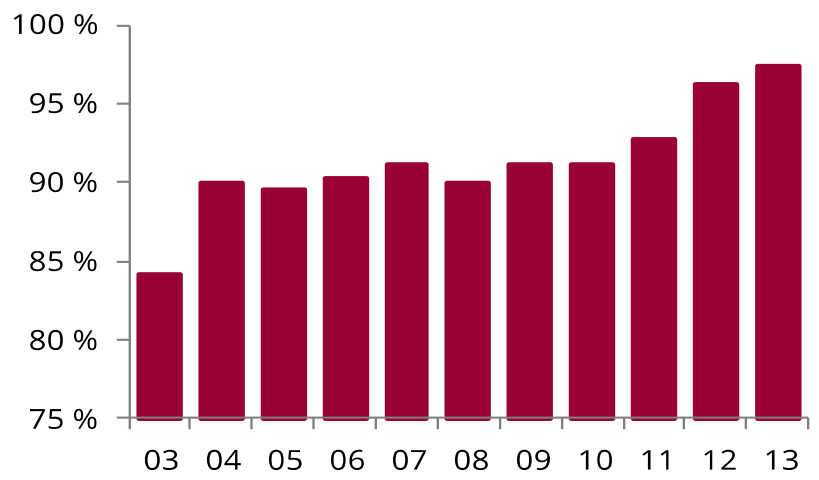

Source: Petrobras

The Abreu e Lima refinery is scheduled to be brought online in two phases. Initially a 60:40 joint venture with Venezuela's PDVSA when construction began in 2006, the refinery was supposed to process 16 degree API Marlim crude and heavy oil from Venezuela to produce mainly diesel. When the facility comes online in Q4 14, it will include two delayed cokers, CDUs, regenerative caustic treatment, hydrogen generation, diesel hydro-treatment, and a naphtha hydro-treatment unit. The refinery project was part of the regional cooperation and integration strategy of South American countries, with a key objective being to meet the increasing demand for oil products in north-east Brazil. However, in late 2013 Brazil officially announced the end of the PDVSA ${ }^{36}$ partnership, after a series of long negotiations between governments in Brasilia and Caracas broke down over the Venezuela's failure to meet its share of the project capex. ${ }^{37}$

The Comperj refinery is believed to be 66 per cent complete as of Q1 14. Several worker strikes have caused delays, with the latest 40-day stoppage only ending in late March after workers accepted a 9 per cent pay increase..$^{38}$ Environmental licence issues and changes to the refinery design have also been blamed for previous delays.

There is an ongoing efficiency drive in place to try and ease the ever increasing gasoline and diesel output-demand differential. Petrobras has a downstream project titled 'Promega', which aims to increase current refining capacity by 0.165 million b/d by 2016 through increasing the efficiency of existing processing units. ${ }^{39}$ The aim is to increase output of diesel, gasoline, and jet fuel. This is much needed, particularly as Brazil has not expanded capacity since the 1980 s, and as a result its hard-pressed refineries are unlikely to continue to operate near their maximum capacity without maintenance or further accidents cutting production. Recent fires suggest breakdowns are becoming more frequent under the strain of continuously high utilization and regulators are considering a crackdown on maintenance practices. Indeed, there has been unrest amongst workers, with union officials claiming that government policies are putting worker safety at risk.

\footnotetext{
${ }^{36}$ Petrobras website, http://www.investidorpetrobras.com, accessed 19 May 2014

37 'Petrobras delays start-up of Abreu e Lima refinery to 2014', Platts, 16 October 2012, http://www.platts.com/latestnews/petrochemicals/tokyo/interview-petrobras-delays-startup-of-abreu-e-8822712/, accessed 19 May 2014

38 'Brazilian workers end Comperj refinery strike', BN Americas, 14 March 2014,

http://www.bnamericas.com/news/oilandgas/brazilian-workers-end-comperj-refinery-strike/, accessed 26 June 2014

${ }^{39}$ Petrobras 2014-2018 Investment plan.
} 

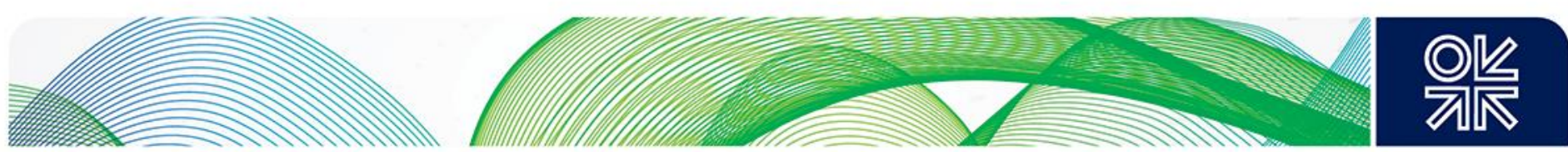

\section{Crude Oil and Product Trade Flows}

Developments in the downstream are closely linked to trade patterns of oil and oil products. Starting with crude oil, Brazil's imports have been steady over the past 13 years at just under 0.4 million b/d, peaking at 0.44 million b/d in 2007, and falling to a low of 0.31 million b/d in 2012.40 Domestically produced crude is classified as heavy or intermediate, therefore, the country imports light crude oil to balance the slate of refineries. In the period 2010-2012, the majority of Brazil's crude oil was imported from Africa $(0.21$ million b/d), largely from Nigeria ( 0.18 million b/d). Brazil also imported around 0.1 million b/d from the Middle East, including around 70 thousand b/d from Saudi Arabia and around 30 thousand b/d from Iraq. ${ }^{41}$

Turning to exports, Brazil sells excess heavy crude, which it cannot process domestically. The trend here has, however, been very volatile, moving in a range of 0.52 million $\mathrm{b} / \mathrm{d}$ from a low of 0.11 million b/d in 2001 to a peak of 0.63 million b/d in $2010 .{ }^{42}$ In terms of export destinations, the largest volumes in the period 2010-2012 were to Asia, where China imported an average 0.21 million b/d, whilst India imported around 63 thousand b/d. North America imported around 0.17 million b/d, the majority of which went to the US. Finally, Central and South America was importing 0.15 million b/d, largely to St. Lucia ( 0.1 million b/d) and Chile (40 thousand $b / d) .43$

Figure 8: Brazil net crude imports, million b/d

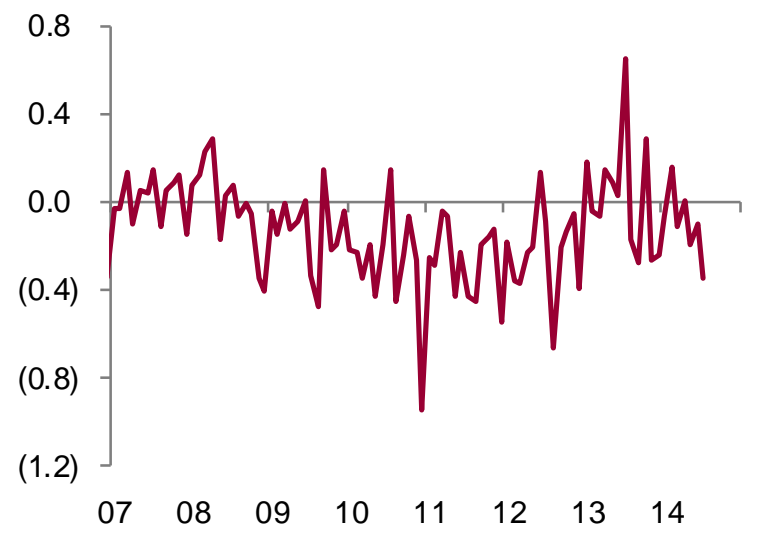

Source: ANP

Due to the strong aforementioned increase in domestic demand, Brazil has become a net importer of oil products, a trend exacerbated by several domestic refining issues. Product imports have risen steadily from a low of below 0.19 million b/d in 2005 to 0.53 million b/d in $2013 .{ }^{44}$ Diesel has seen the largest rise in product imports, rising from 41 thousand b/d in 2005 to a peak of 0.18 million b/d in 2013. Gasoline imports, which were previously close to zero, have averaged 51 thousand b/d over the past three years. ${ }^{45}$ In terms of product exports, diesel exports have remained below 10 thousand $b / d$ on average over the past 13 years.

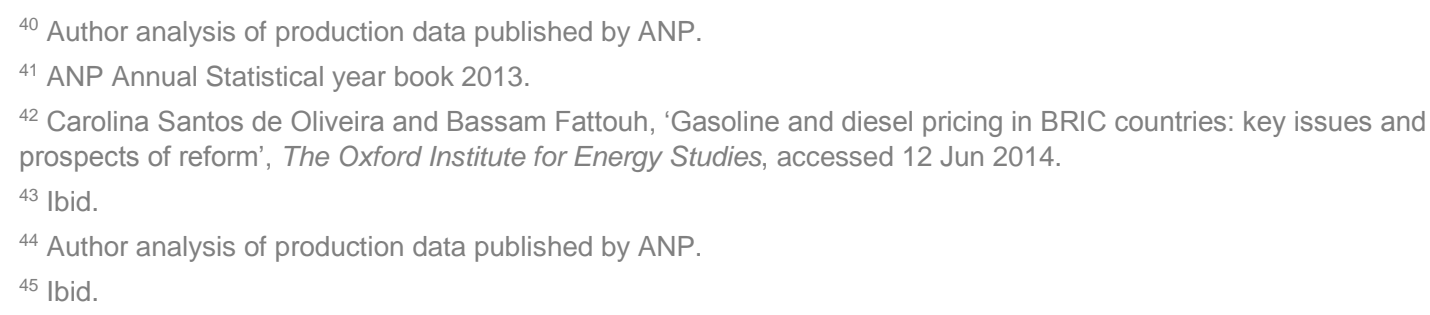



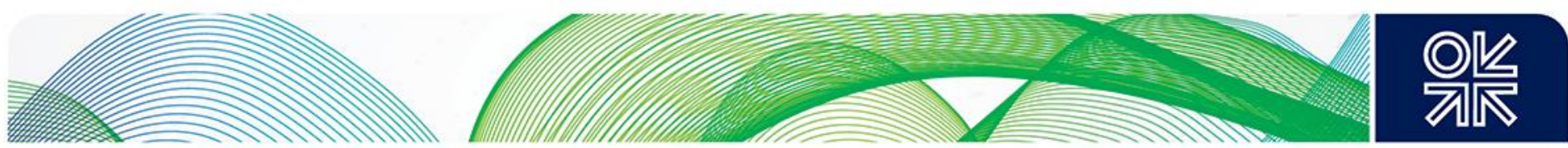

Gasoline exports, which averaged 44 thousand b/d between 2000 and 2010, have fallen to 4 thousand b/d since 2011. The main export product is fuel oil (including bunker fuel) of which Brazil has exported around 0.15 million b/d over the last three years. ${ }^{46}$

Figure 9: Brazil oil product imports, million b/d

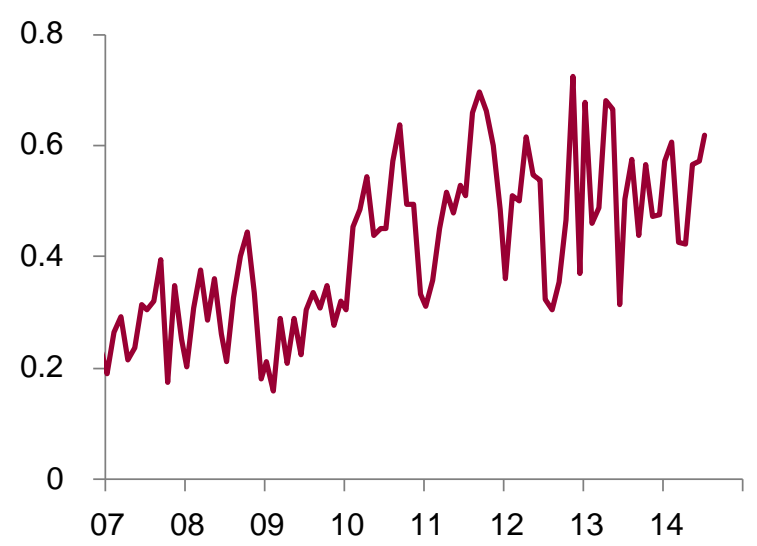

Source: ANP 

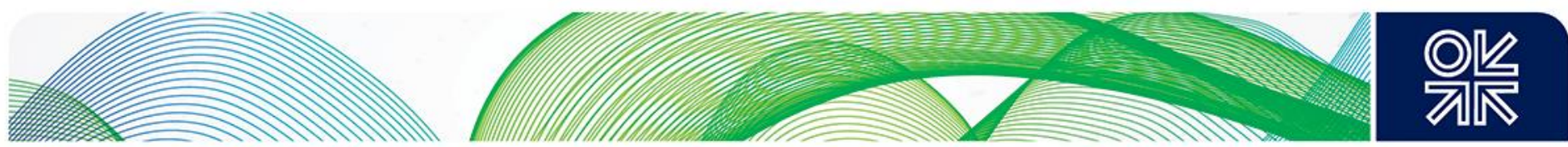

\section{Oil Sector Regulatory Reform}

As mentioned previously, Petrobras controls 90 per cent of upstream oil production in Brazil, and held exclusive operating rights until 1995. In that year, an amendment to article 177 of the Federal Constitution allowed for the presence of other oil companies in upstream operations, while still maintaining oil 'in situ' as a State property ${ }^{47}$ Four main statutes have been enacted to regulate oil activities in Brazil since then: Law 9,478, in 1997, and Laws $12,351,12,304$, and 12,276, in 2010 , when the regulatory framework was reformed after the pre-salt discoveries.

Law 9,478, also called 'the Petroleum Law', introduced a concession regime. Fiscal appropriation under this regime takes place via signature bonus, royalties ranging from 5 to 10 per cent, retention payments, and a special participation tax for productive areas. The law also created the National Energy Policy Council (CNPE) and the Brazilian National Petroleum Agency (ANP). The latter is responsible for regulating the oil industry in the country, while the former is an advisory Council composed of ministers and linked to the Presidency of the Republic. It is responsible for elaborating energy policy proposals and guidelines about the rational use of energy resources.

Law 12,276 provided for an onerous relinquishment regime, according to which 5 billion barrels of exploration rights were transferred to Petrobras with due compensation. Since Law 12,351 established a production sharing system in the newly discovered pre-salt basin and areas deemed strategic, three different exploration models are currently in place in Brazil. The onerous relinquishment model, specific to a certain region of the pre-salt basin ${ }^{48}$, the production sharing system, in all the pre-salt region and strategic areas after the enactment of Law 12,351, and the concession regime, governed by Law 9,478, which applies to all other areas. Until 2010 Law 9,478 was the main statute regulating oil activities in Brazil, which meant that oil exploration took place exclusively via concessions. Most specialists consider it to have been a very successful regulatory framework because of the significant development of the domestic oil and gas sector in the decade after it was enacted. ${ }^{49}$

Law 12,351 also created a social fund and gave Petrobras the right to operational exclusivity in the pre-salt basin and in areas deemed strategic. International oil companies are authorized to invest in these domains, but may only hold a maximum 70 per cent share in consortia because Petrobras must have a minimum 30 per cent share. Pre-Sal Petróleo SA (PPSA), an entirely state-owned enterprise, was created by Law 12,304 to monitor and manage production sharing contracts signed with winning consortia of public tenders. An operational committee will be formed and will be responsible for the central decisions within these consortia, with the presidency and 50 per cent of the seats on the committee assigned to PPSA and the rest to the participating companies according to their capital share.

\footnotetext{
${ }^{47}$ Constitution of the Federative Republic of Brazil, http://www.stf.jus.br/repositorio/cms/portalStflnternacional/portalStfSobreCorte en us/anexo/constituicao ingles 3ed 2010.pdf, accessed 17 August 2014

${ }^{48}$ Article 2, I of Law 12,276.

${ }^{49}$ Cf. i) Adilson De Oliveira, 'Brazil's Petrobras: strategy and performance' in Victor, DG, Hults, DR and Thurber, M, Oil and Governance, Cambridge University Press, Cambridge (2012); ii) FABIO GIAMBIAGI, Petróleo: reforma e contrarreforma do setor petrolífero brasileiro (Elsevier Brasil 2013); iii) Ednilson Silva Felipe, 'Mudanças Institucionais E Estratégicas Empresariais: A Trajetória EO Crescimento Da Petrobras a Partir Da Sua Atuação No Novo Ambiente Competitivo (1997-2010)' (2010); and iv) GUILHERME GOMES DIAS, 'MUDANÇA INSTITUCIONAL E DESENVOLVIMENTO: O CASO DA INDÚSTRIA DO PETRÓLEO NO BRASIL' (2013).
} 

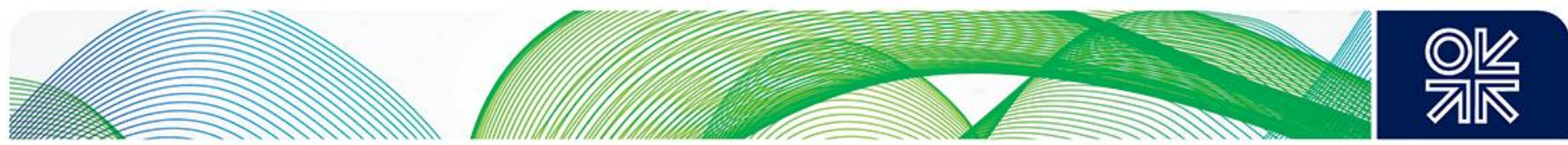

\section{The Implications of the Reforms}

2010 was, therefore, an important milestone in the history of the Brazilian oil sector with the enactment of laws $12,351,12,304$ and 12,276 . The reforms have undoubtedly shaped the rate, or rather lack, of progress in the Brazilian upstream sector. Once the scale of the presalt region became apparent after the Tupi discovery, the government suspended auction rounds offering new acreage for exploration to oil companies and set out to rewrite Brazil's oil laws. Due to the excessive bureaucracy that plagues Brazil, and many other resource-rich nations, this process took several years. Some argue that the uncertainty surrounding the reforms halted what had previously been annual auctions. Leases sold through such auctions helped more than double Brazilian crude output from under 0.9 million b/d in 1997 to 1.9 million b/d in 2008. ${ }^{50}$

Petrobras' operational exclusivity in the pre-salt basin and strategic regions granted by Law 12,351 is one of the most criticized aspects of the new statutes, since it may entail important drawbacks in the Brazilian oil sector. Because of the significant investments required in exploring such an enormous area, exclusivity has three possible consequences:

- A considerable reduction in the pace of exploration because of Petrobras' difficulty in coping with the huge investments required to be able to explore this vast area.

- A significant increase in Petrobras' debts to finance exploration activities.

- Reallocation of the company's international projects to allow focus on domestic exploration and the pre-salt basin.

The evidence to-date suggests that all of the above are already occurring to a varying degree. A further concern is that exclusivity may deter investment by making these areas less attractive to foreign oil majors. IOCs usually invest in other countries via joint ventures that allow them to have an effective say on most important decisions. In such cases, they are fully aware and informed of the technical implications and repercussions of their deliberations. Brazil's exclusivity requirements raise the risk of international investors becoming mere capital donors, writing blank cheques without an effective say in important decisions. This outcome is quite possible because, as previously mentioned, according to Law 12,351 all consortia formed to explore pre-salt and strategic areas in Brazil should be managed by an operational committee, where PPSA will hold 50 per cent of the seats and elect its president. Therefore, PPSA will have a preponderant voice in all deliberations, despite not necessarily contributing capital. Clearly, in an environment where upstream investments are getting ever riskier in nature this framework becomes less and less appealing.

\section{Local Content}

Given the significant restrictions placed on foreign involvement, the Brazilian government has pushed Petrobras in the direction of developing a huge technologically and geologically complex basin by itself. This process took decades and a collaborative effort from several major oil companies in other big basins such as the North Sea. There is no doubt about the technical ability of, for example, the pre-salt team. According to industry leaders, Petrobras' deepwater expertise ranks amongst the best globally. However, as Petrobras has been saddled with mandates and heavy government interference, overburdening the company with tasks such as reviving the shipbuilding industry, this has left the company spread thinly. For example, Petrobras and its partners must use oil platforms and equipment built in Brazil, according to the established local content policy, which industry experts estimate has led to cost overruns as high as 50 per cent.

\footnotetext{
${ }^{50}$ Author analysis of production data published by ANP.
} 

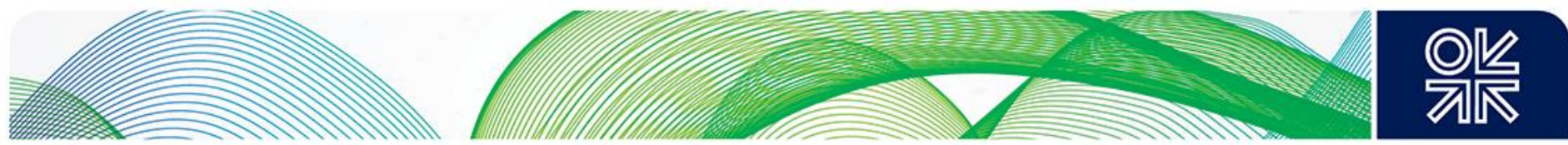

Since the development of a robust local industry for oil equipment is one of the goals of the law enacted in 2010 , local content requirements are expected to play an increasingly large role in the future. In the first bidding round in pre-salt areas the required percentages were between 55 per cent and 59 per cent at the development phase and 37 per cent at the exploration phase. This policy is understood to have played a key part in the significant increase in production costs and in delaying the accomplishment of existing projects. ${ }^{51}$

\section{Lack of Adjustment in Prices for the Local Market}

Meanwhile, just as the politicians are placing the huge burden of developing the pre-salt on the shoulders of Petrobras, they have financially undercut their ability to do so through the implementation of subsidies on oil products such as gasoline and diesel. Whilst efforts have been made to try and stem losses in the downstream by increasing domestic oil product prices, the differential between domestic and international prices continues to impact the downstream. In 2013, diesel prices were adjusted twice and gasoline prices three times, which represented a 20 per cent increase in domestic diesel prices and 11 per cent in gasoline. ${ }^{52}$ Whilst May 2013 saw the achievement of near parity between domestic and international prices for a period of a month, a significant devaluation of the Brazilian currency then led to a deeper gap between oil prices in Brazil and abroad.

Recent years have seen other price rises. In November 2011 gasoline prices were raised by 10 per cent and diesel by 2 per cent,,$^{53}$ then in 2012 there was a 7.8 per cent increase in gasoline and 10.2 per cent for diesel. ${ }^{54}$ The effect of price increases to retail customers has been partially offset by the Brazilian federal government's move to reduce the fuel tax (also known as CIDE) for gasoline and diesel, which is currently $0 \% .{ }^{55}$ However, despite the price increases, Brazil's gasoline and diesel production has lagged domestic demand for the majority of the last 14 years, and the difference between the two has widened most substantially over the past few years. The introduction of subsidies arguably incentivized the use of gasoline (over ethanol) in cars and diesel for power generation, while developing regions in Brazil are understood to run diesel-guzzling generators at peak times to avoid expensive electricity tariffs during these hours.

Petrobras' corporate governance structure largely explains its pricing policy. Key board members come from economic ministries of government and they are increasingly using Petrobras to tackle inflation by blocking the ability of the company to increases fuel prices in line with international markets. Indeed, the president of the board comes from the influential Ministry of Finance, which has been revealing a tendency to resist necessary prices increases.

\section{Overlapping Responsibilities}

The legislation enacted in 2010 also adds elements of uncertainty to governance mechanisms among the different bodies of the Brazilian oil sector. While statutes have contributed to more clearly defining institutional competencies, the very creation of a new regulatory regime and a

\footnotetext{
${ }^{51}$ Cf. i) Eloi Fernandez and Bruno Musso, 'Oportunidades e Desafios da Agenda de Competitividade para Construcao de uma Politica Industrial na Area de Petroleo: Proposatas para um Novo Ciclo de Desenvolvimento Industrial' Estudos e Pesquisas No. 384 Instituto Nacional de Altos Estudos; ii) Jose Renato Ferreira de Almeida, Conclusoes e Recomendacoes de Politica (Estudo da Competitividade da Industria Brasileira de Bens e Servicos do Setor de P\&G, 2007); iii) Roberta Paduan, O Maior Desafio do Pais (2012)and iv) Guimaraes, 'Uma avaliacao da politica de conteudo local na cadeia do petroleo e gas'.

52 Petrobras 2013 Annual Results.

53 lbid.

54 Ibid.

${ }^{55}$ Carolina Santos de Oliveira and Bassam Fattouh, 'Gasoline and diesel pricing in BRIC countries: key issues and prospects of reform', The Oxford Institute for Energy Studies, Accessed 12 August 2014.
} 

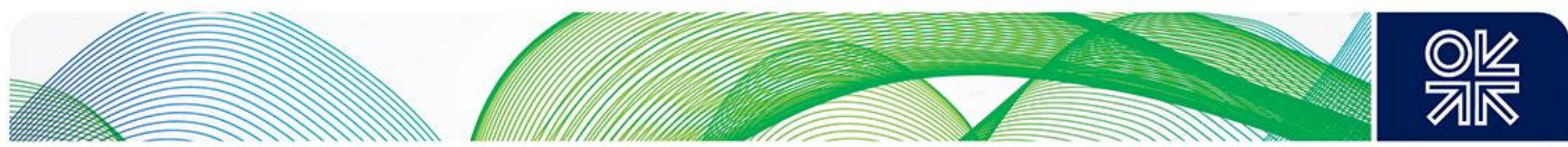

wholly state-owned company to interface with existing bodies generates uncertainties about how they interact and influence the sector.

Investors will be particularly concerned about the composition of PPSA, because of its importance in the newly established regime and its influence over the main decisions in presalt and strategic areas. For instance, PPSA's relationship with Petrobras is critical, since the two companies are expected to hold the majority of seats in the operational committee for all consortia. There are a number of uncertainties. Will PPSA be able to block important operational decisions in a way that benefits Petrobras to the detriment of other members of the operational committee? Petrobras is controlled by the government and is undeniably one of the most-important companies in Brazil. How will PPSA and ANP interact? The answers to all these questions evoke uncertainties and future challenges.

Notwithstanding these aspects, the 2010 reforms have also brought positive elements, especially regarding the clearer definition of attributions between institutions. One of the reforms' objectives was to concentrate more policy formulation powers within central governmental entities directly linked to the president, such as the Ministry of Mines and Energy (MME) and CNPE. ${ }^{56}$ ANP was mostly left only to focus on primarily regulatory functions. While the statutes enacted in 2010 created challenges with respect to governance mechanisms between newly formed bodies and existing ones, they provided a clearer demarcation of roles among them. MME was given responsibility for defining the technical and economic parameters for auctions and production sharing contracts. ${ }^{57} \mathrm{It}$ also assumed the role of proposing to CNPE the area of the blocks to be auctioned. These competences were not clearly defined in Law 9,478, the existing statute before the enactment of Law 12,351. CNPE's role was also more precisely detailed, aiming to overhaul its policy formulation functions.

A more accurate delimitation of functions between governmental bodies increases transparency, accountability, and helps to avoid problems of one institution occupying a particular function it was not specially designed for due to legal loopholes or grey areas. According to several Brazilian scholars that is what happened in Brazil with ANP from 1997 to 2002. 58 During this period, the agency was considered to have assumed main policy formulation functions to the expense of the Ministry of Mines and Energy and CNPE.

Another positive aspect of the reforms was the creation of the Social Fund, ${ }^{59}$ which meant that for the first time the Brazilian oil legislation inscribed a set of systematized and consistent programmes of social development. Financial resources for the fund are drawn from the royalties allocated to the federal government in pre-salt domains and areas identified as strategic, along with a percentage of the signature bonuses from production sharing agreements. ${ }^{60}$ In the future, the social fund is expected to become an important source of reserves to finance educational and social projects in the country. Apart from this social dimension, it is also considered a typical stabilization fund as it aims to reduce abrupt macroeconomic fluctuations due to changes in global oil prices. ${ }^{61}$

\footnotetext{
${ }^{56}$ E.S Felipe, 'Mudanças Institucionais E Estratégicas Empresariais: A Trajetória e o Crescimento Da Petrobras a partir da sua Atuacao no Novo Ambiente Competitivo' Rio de Janeiro, 1997-2010.

${ }^{57}$ Article 10 of Law 12,351 .

${ }^{58}$ Cf. Bernardo Mueller and Carlos Pereira, 'Credibility and the Design of Regulatory Agencies in Brazil' Brazilian Journal of Political Economy, 22 (3) 2002, 81-82 and Edson Nunes and others, Agências reguladoras e reforma do Estado no Brasil: inovação e continuidade no sistema político-institucional, 2007.

${ }^{59}$ Article 47 of Law 12,351 .

${ }^{60}$ Article 49 of Law 12,351.

${ }^{61}$ Mark Allen and Jaime Caruana, 'Sovereign Wealth Funds: A Work Agenda,' 29, International Monetary Fund, Feb 292008.
} 

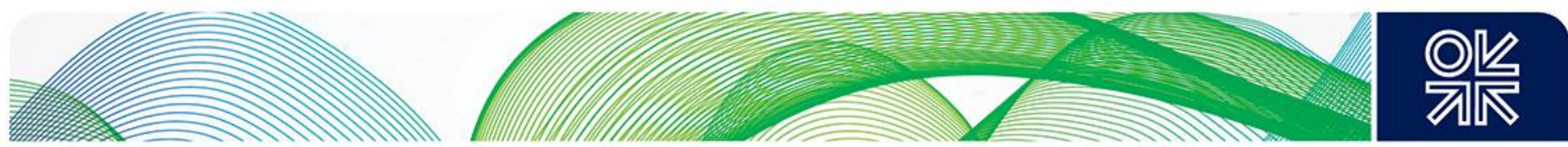

\section{Other Challenges: High Decline Rates and Cost Escalation}

In addition to regulatory and governance issues, there are numerous technical and environmental challenges in turning below-ground potential into above-ground production. Brazil has had to work harder than the majority of resource-rich nations, as over 90 per cent of Brazil's production comes from offshore basins, the majority of which are categorized as deepwater. Petrobras has become a leader in offshore exploration and production, which has been critical for the development of Brazil's pre-salt reservoirs. Reserves across the Santos and Campos basins are rooted deep under layers of salt up to two kilometres deep, ${ }^{62}$ known in the industry as ultra-deepwater. Many of the pre-salt fields are located 200-300 km away from the coast, so high-pressure drills with anti-corrosive coating are needed to get through the thick layers of salt.

Nevertheless, pre-salt production has breached 0.5 million b/d as of June $2014,{ }^{63}$ and the discovery to production period of less than eight years surpasses previous large discoveries in other parts of the world - a commendable feat. In the North Sea the equivalent production level was reached after nine years, whilst such output levels from deepwater Gulf of Mexico took 17 years. Whilst the increasing output levels indicate that technical and geological challenges are being overcome, scaling up production remains a substantial challenge due to project delays, cost inflation, and steep decline rates from legacy assets. The latter warrants closer inspection and will be discussed in greater detail below.

\section{High Decline Rates}

In a recent report, ${ }^{64}$ the authors analyzed recent well data available from the ANP and found that double-digit declines in existing fields are offsetting the efforts being made in upstream. ${ }^{65}$ The main conclusion of the report is that on an annual basis average production declines are between 17 per cent and 20 per cent. ${ }^{66}$ This number increased from 14 per cent in 2005 to 23 per cent in 2011, before falling back to 21 per cent in 2012 and 17 per cent in 2013. With decline rates of 17 per cent and around 2 million b/d of liquids output, 0.3 million b/d of production needs to be brought online each year to keep output stable. Given such steep levels of decline, any equipment and project delays quickly show up in a declining production trend. Broadly speaking, more than one large FPSO is needed each year to offset declines and that number rises as the field ages. This holds particularly for pre-salt discoveries. The new pre-salt discoveries are concentrated in the Santos Basin, yet their output currently only accounts for around 20 per cent of Brazil's total production, the bulk of which comes from the shallower deposits of the Campos Basin in the waters off Rio de Janeiro. The challenge has been that while the vast pre-salt developments require heavy investment, the ever maturing fields of the Campos have required some attention of their own given the alarming rate at which they have been declining.

\footnotetext{
62 'Pre-salt oilfield creates biggest challenge yet for Petrobras', The Financial Times, Oct 22 2013, http://www.ft.com/cms/s/0/81a51734-25ec-11e3-8ef6-00144feab7de.html\#axzz38ZnxXkYW, accessed 18 Aug 2014

63 'Pre-salt production breaks new record and surpasses 500 thousand barrels of oil per day' Petrobras, http://www.investidorpetrobras.com.br/en/highlights/detalhe-21.htm/, accessed 18 Aug 2014

${ }^{64}$ Cf. i) Eloi Fernandez and Bruno Musso, 'Oportunidades e Desafios da Agenda de Competitividade para Construcao de uma Politica Industrial na Area de Petroleo: Proposatas para um Novo Ciclo de Desenvolvimento Industrial' Estudos e Pesquisas No. 384 Instituto Nacional de Altos Estudos; ii) Jose Renato Ferreira de Almeida, Conclusoes e Recomendacoes de Politica (Estudo da Competitividade da Industria Brasileira de Bens e Servicos do Setor de P\&G, 2007); iii) Roberta Paduan, O Maior Desafio do Pais (2012)and iv) Guimaraes, 'Uma avaliacao da politica de conteudo local na cadeia do petroleo e gas'.

${ }^{65}$ ANP well data.

${ }^{66}$ Amrita Sen, Virendra Chauhan, Maarten van Mourik and Pedro Florenco, 'Brazil's Struggles', Energy Aspects, April 2014.
} 

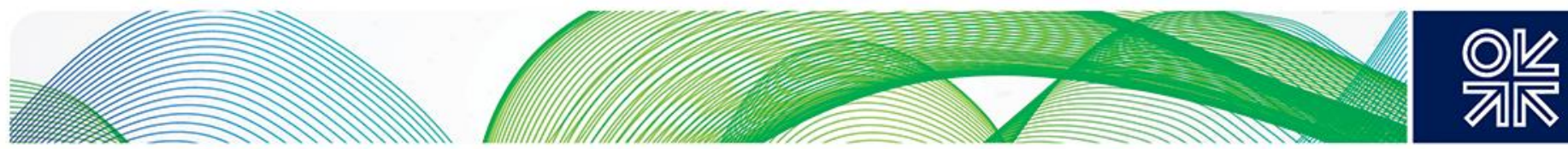

In addition to Petrobras not being able to meet its optimistic pre-salt production forecasts, there are several reasons for these production declines. These range from delays in the delivery of equipment to mishaps such as the Frade oil leak, which curtailed production for over a year. However, since 2000, according to the authors' analysis, 4 million b/d of production processing capacity has been installed in offshore Brazil. Over the same period actual production increased from 1 million $\mathrm{b} / \mathrm{d}$ to 1.8 million $\mathrm{b} / \mathrm{d}$. Production increased from 1 million $\mathrm{b} / \mathrm{d}$ to 1.5 million $\mathrm{b} / \mathrm{d}$ over a six-year period, but then the next incremental 0.3 million $\mathrm{b} / \mathrm{d}$ took another three years, after which production then stagnated at 1.8 million $\mathrm{b} / \mathrm{d}$ for four years. According to the data collated from ANP and BDEP, some 0.9 million b/d of processing capacity was installed between 2010 and 2012, with another 0.4 million b/d in 2013.

Thus, Brazil's performance has not been a result of a lack of activity, quite the contrary. Since 2005 , in deepwater alone, every year some 34 wells have been put on stream, with an average productivity varying from 6 thousand b/d in 2010 to a high of 11 thousand $b / d$ in 2012, with an average of 8/9 thousand b/d over the period. Such flow rates make shale oil developments look comparatively poor, where flow rates are typically less than 1 thousand b/d. ${ }^{67}$ The number of wells brought on stream in shallow and medium water depths is slightly less, with an average 24 wells being brought online every year. The new shallower wells have much lower average output levels, at some $600 \mathrm{~b} / \mathrm{d}$ in 2008-2010. That profile changed in 2011 , when the average output increased from $1,800 \mathrm{~b} / \mathrm{d}$ to $2,500 \mathrm{~b} / \mathrm{d}$ in 2013 , however, the average disguises the fact that the latest field in shallow/medium water depths, Bauna, has wells flowing at close to 20 thousand b/d. In fact, a tally of the producing wells by flow rates shows that Brazilian output is dependent on a fairly small number of high-productivity wells.

Figure 10: Brazil's offshore production by field vintage, million b/d

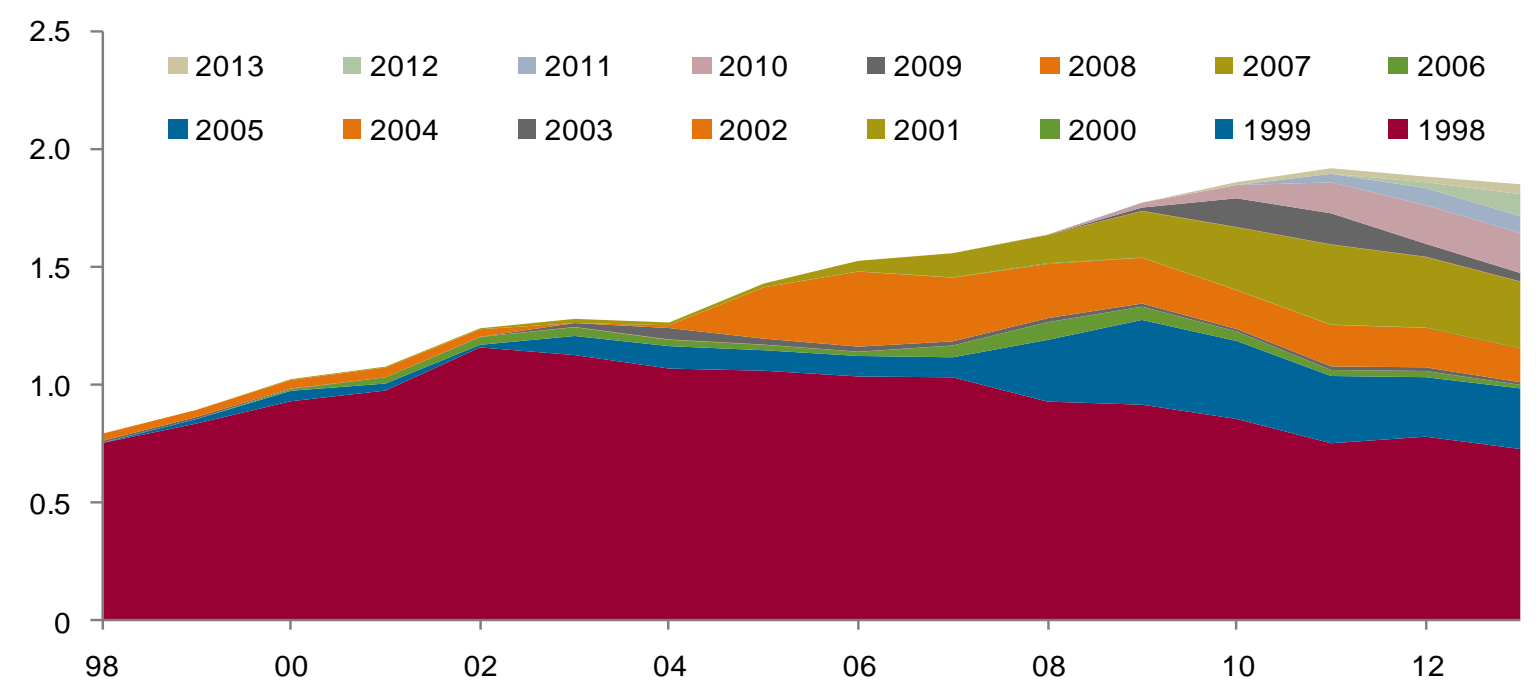

Source: Energy Aspects

\footnotetext{
7 'Analysis of well completion data for Bakken oil wells', Resilience, Nov 25 2013, http://www.resilience.org/stories/2013-11-22/analysis-of-well-completion-data-for-bakken-oil-wells/, accessed 18 Sept $\underline{2014}$
} 

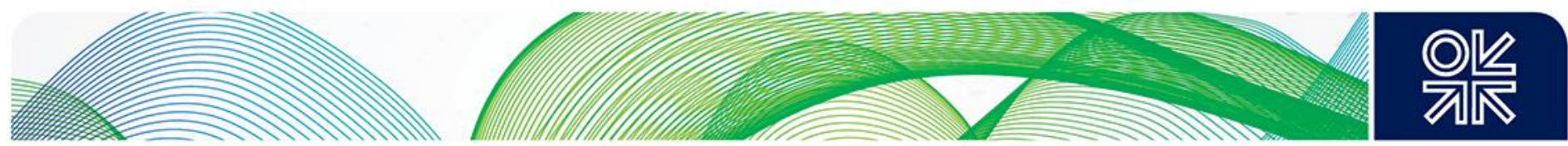

Figure 11: Brazil's deepwater production by well vintage, million b/d

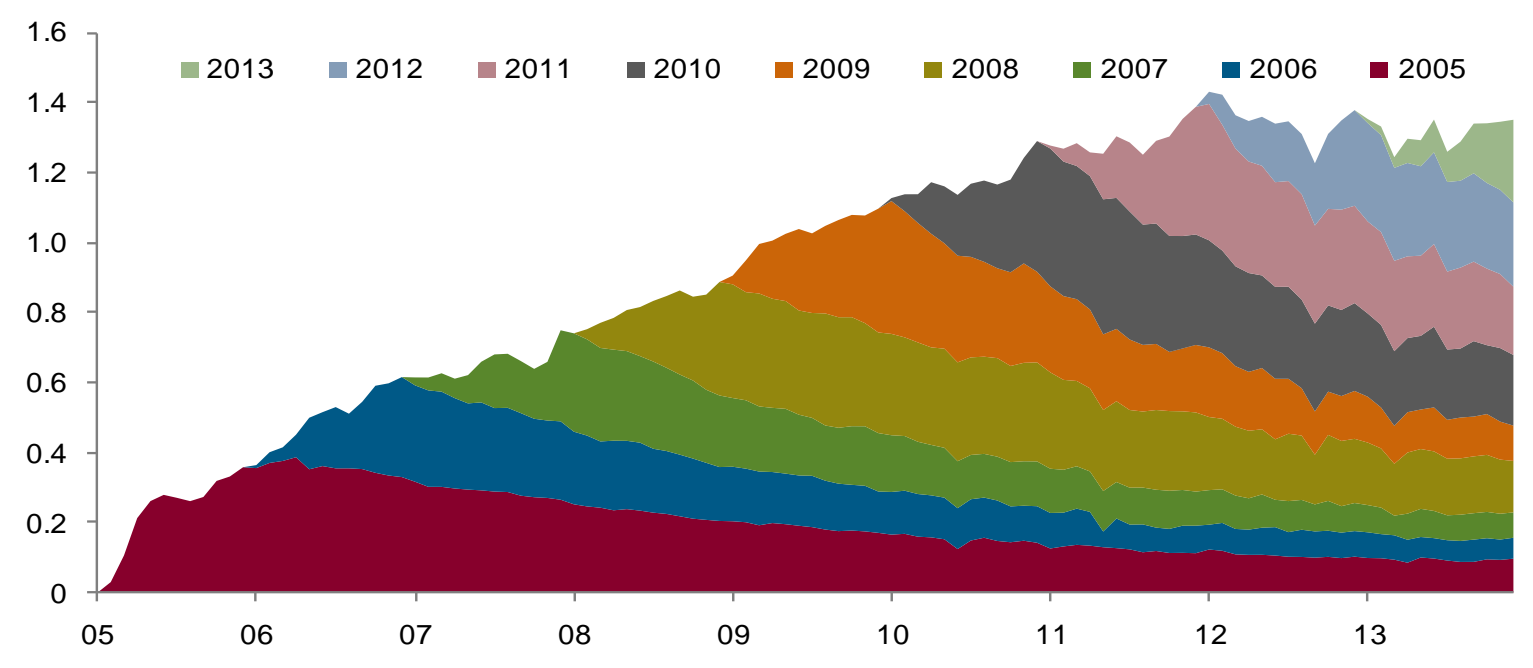

Source: Energy Aspects

The production profiles of the wells can be assessed in two different ways. The first is to group the wells by vintage and then look at the annual profile. The second is to look at a standardized profile with all wells normalized at month one. Using the first approach, we find that deepwater wells that started producing in 2005 had an average output in year one of between 1.5 and 2 times the level observed in the start-year. In year two, production falls to between 70 per cent and 90 per cent of the level in year one, and then in year three, it is between 76 per cent and 84 per cent of year two production and so on. Looking at the well profiles normalized to their first month, and grouped by size class, shows that the wells reach peak capacity by the second month of production. Wells with maximum productivity of between 5 thousand and 10 thousand b/d, sustain their peak output for about one month and then production drops to 60 per cent of output by the 12th month of production. Wells producing more than 10 thousand $\mathrm{b} / \mathrm{d}$ at maximum output have a more gentle profile, with production falling to 70 per cent of peak output by the 12 th month.

In short, our analysis indicates that double-digit declines in existing fields are offsetting the efforts being made in the upstream. Broadly speaking, more than one large FPSO is needed each year to offset declines and that number rises with ageing of the fields and installation of more equipment in new fields. ${ }^{68}$ Brazil has installed around 4 barrels of production capacity for a net gain of 1 barrel in output over the past 12 years. It is no surprise then that Petrobras has had difficulties reaching its various production goals as presented in the annual strategic plans over the years. Delays in construction are only too common and, given the decline rates, such delays translate into immediate production drops.

\footnotetext{
${ }^{68}$ The evidence from Brazil has strong implications for the broader non-OPEC supply outlook given that the key agencies (IEA, EIA, OPEC) base their forecasts on fairly static decline rates. However, given the increasing dependence on unconventional production such as deep and ultra-deepwater production, be that in Brazil or the US Gulf of Mexico, or OPEC nations such as Angola and Nigeria where average decline rates are clearly on the rise, if the traditional sources of growth are declining at such rapid levels this brings the required level of growth required each year into the limelight.
} 

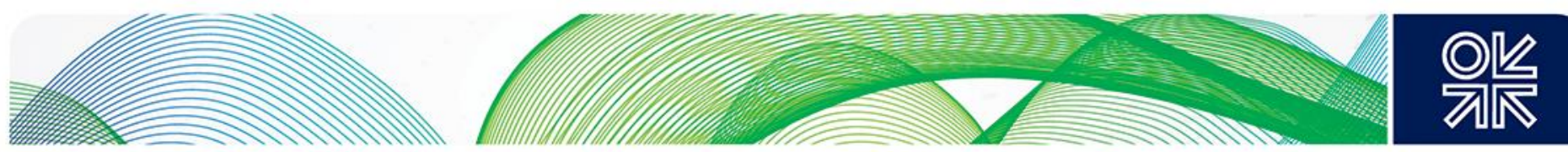

\section{Cost Escalation}

Cost escalation has also played its part. The evolution of Petrobras' 5 -year business plan is a tale of increased costs and production target misses, and though the latter have become a well-known feature for major oil companies over the years, ${ }^{69}$ Petrobras perhaps epitomises the challenges facing the upstream sector. Petrobras' E\&P capex has increased almost 2.5 fold, from $\$ 65.1$ billion in 2008 to $\$ 153.9$ billion in its $2014-2018$ business plan. The percentage of capital allocated to E\&P has increased from 58 per cent to 70 per cent, with Petrobras' total five-year capex increasing from $\$ 112.4$ billion to $\$ 220.6$ billion. The investment programme was revised upwards for five consecutive years, and only in 2014 did Petrobras reduce its overall capex programme by $\$ 16.1$ billion, although this was solely attributable to a $\$ 26.1$ billion downward revision to spending in the refining, transportation, and marketing division.

\section{Figure 12: Petrobras 5-year capex programme, $\$$ bn}

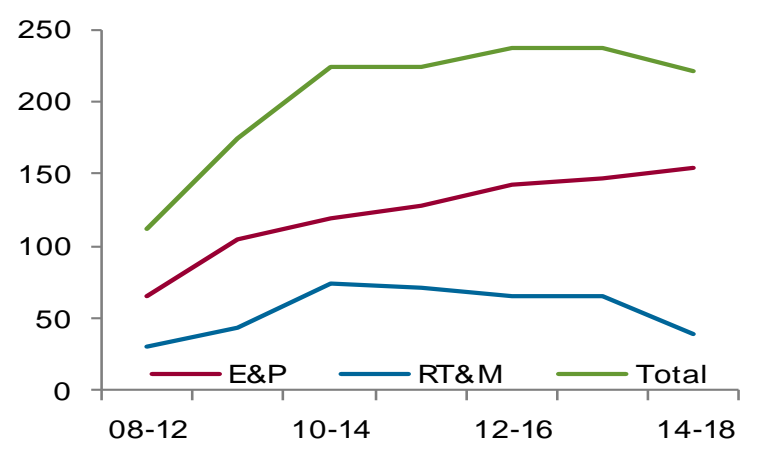

Source: Petrobras

A lot has happened between 2008 and the latest 5-year business plan, including a deep global recession, a doubling of oil prices, and a tight-oil revolution in the US. Of course these factors were beyond Brazil's control, though an analysis of how Petrobras' business plan has evolved in response to the changing regulatory framework over the past six years illustrates the stark contrast between production targets and reality (see Appendix for summary of key changes in Petrobras' business plan). Significantly, until the second quarter of 2014, the sharp increase in investment in the upstream had not been rewarded with an uptick in production. As previously discussed, production has fallen year-on-year by an average of 2 per cent in 2012 and 2013, but there have been downward revisions to futures estimates through to 2020 - by as much as 1 million b/d at certain points. ${ }^{70}$

\footnotetext{
69 'US oil booms, yet big oil struggles to reap benefits', CNBC, 5 Aug 2013, http://www.cnbc.com/id/100936044/, accessed 12 Sept 2014

${ }^{70}$ Petrobras 2014-2018 Investment plan.
} 

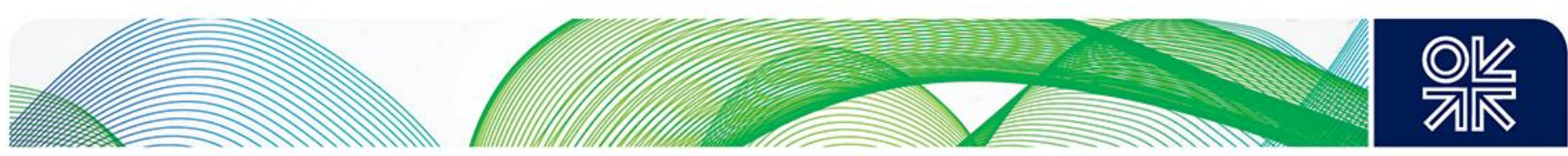

Figure 13: Petrobras production downgrades, $\mathrm{mb} / \mathrm{d}$

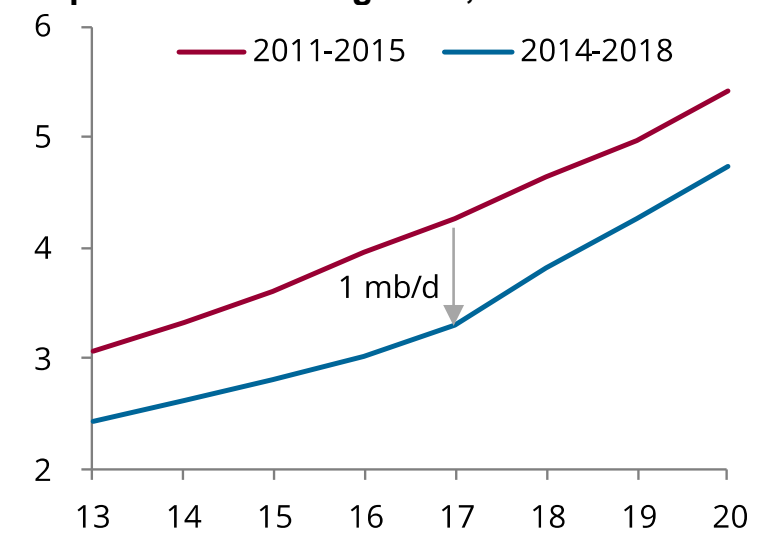

Source: Petrobras 2014-2018 plan

Petrobras has seen a sharp rise in production costs for existing wells, as well as in costs related to equipment and facilities, labour, and materials. Production costs in 2011 and 2012 on average were 36 per cent higher than in 2010, and data for 2013 indicate a similar trend. ${ }^{71}$ The 10-year compound annual growth rate (CAGR) in production costs is 22 per cent. From 2003 to 2013, production costs have moved largely in line with oil prices. Given oil has, on a quarterly basis, remained steady at around $\$ 110$ for three years now and Petrobras continues to experience rising costs, the financial picture is unsurprisingly looking less positive.

\section{Figure 14: Petrobras Production Costs}

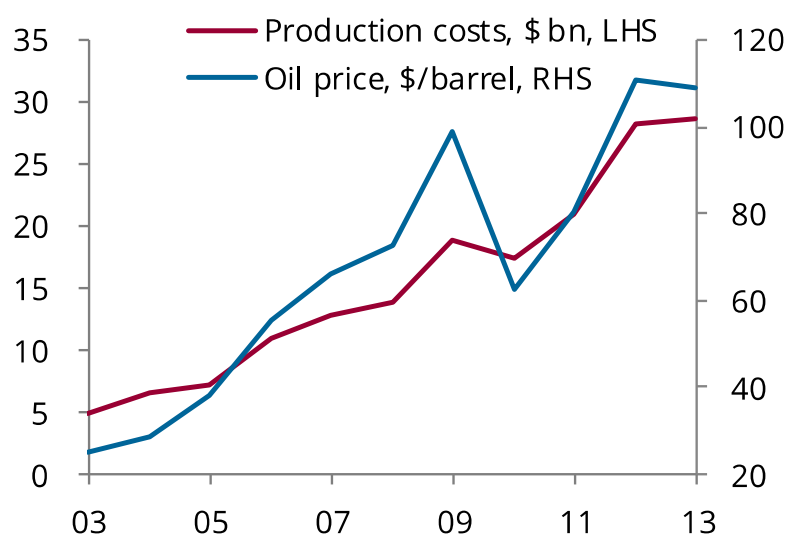

Source: Petrobras

Cost increases were not limited to existing production. In the same period, Petrobras' general and administrative expenses (on a 10-year CAGR basis) increased by 17 per cent due to salary increases, a larger workforce, training costs, and increased third-party technical services. ${ }^{72}$ Meanwhile, exploration costs at the group level were 19 per cent higher on a 10year CAGR basis due to an increase in the operational activity and higher write-off amounts for dry wells. Research and development expenses, whilst on a downward trend since peaking at nearly $\$ 1.5$ billion in 2011 , have been above the $\$ 800$ million average in the fiveyear period between 2005 and 2009. Similarly, organic finding costs have been rapidly rising from the low levels that Petrobras used to enjoy, averaging $\$ 7.3$ per barrel over the last three years, compared to the sub $\$ 1$ levels seen in the early parts of the last decade.

\footnotetext{
${ }^{71}$ Based on analysis of FAS-69 data from SEC filings.

72 Petrobras 2012 Annual results.
} 

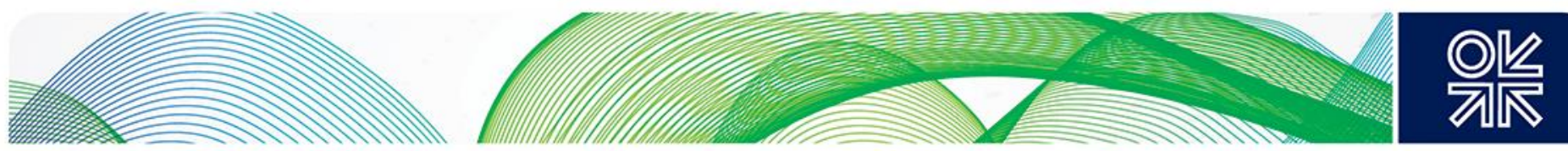

Currently, Petrobras estimates the breakeven cost of its production to be $\$ 45-\$ 55$ per barrel for the pre-salt. ${ }^{73}$ This cost estimation is based largely on both the pool of existing conventional resources and the assumption that all of its reserves will be transformed into revenues. The high degree of complexity involved in deep and ultra-deepwater extraction requires expensive technology and manpower, while the existence of several technical challenges requires further expenditure to overcome them. ${ }^{74}$ Also, unlike easily accessible conventional oil, there are high costs involved in getting the oil onshore from wells that involve distances of $340 \mathrm{~m}$ to $800 \mathrm{~km}$. The change in the regulatory framework also contributes to increasing breakeven costs. In the Libra field, for example, the Brazilian government requires a $\$ 6.9$ billion bonus, which, reduces returns for foreign participants by more than 10 per cent and increases the required production rates to achieve economic internal rates of return. In June this year, Brazil paid almost $\$ 7$ billion for deepwater rights to produce from a region which holds the Buzios field. ${ }^{75}$ In order to help shoulder some of the costs, the company is believed to be considering selling assets and restructuring other projects. 

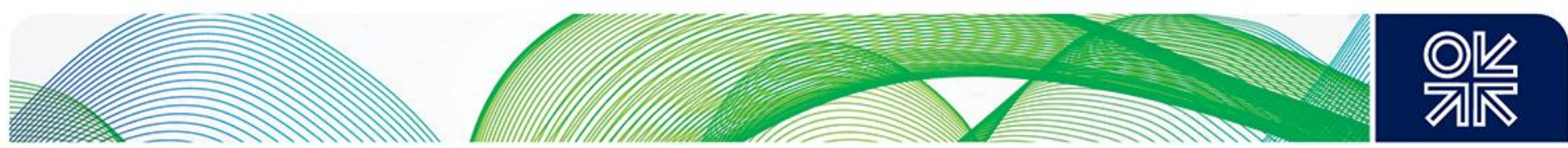

\section{Conclusions and Implications for the Global Oil Market}

Brazil's upstream prospects will undoubtedly play a key role in keeping the oil market in balance over the near term. Discoveries such as Tupi and Libra have catapulted Brazil into the limelight, with key agencies such as the IEA, EIA, and OPEC suggesting that Brazil will play a critical role in the broader non-OPEC supply outlook. Back in 2006, the IEA predicted Brazil's output to surpass 3 million b/d by 2009; that expectation now extends to 2018. Petrobras, meanwhile, has lowered its production targets consistently over the past few years as oil output growth continues to disappoint. This is not due to disappointing results from Brazil's pre-salt production. Quite the contrary; it has reached almost $0.6 \mathrm{mb} / \mathrm{d}$ in August 2014, and the discovery to production period of seven years surpasses previous large discoveries in other parts of the world. However, recent experience suggests that scaling up production remains a substantial challenge.

This paper identifies four key hindrances to Brazil's oil sector:

Cost escalation - in both the upstream and downstream. The global upstream sector has been challenged by rising costs and Petrobras has epitomized this theme. On a 10-year CAGR basis costs have risen by 22 per cent, while the past three years have seen costs rise by more than 30 per cent per year from 2010 levels.

Decline rates - double-digit declines in existing fields are offsetting the positive benefits of new projects coming on stream. Broadly speaking, more than one large FPSO $(0.2 \mathrm{mb} / \mathrm{d})$ is needed each year to offset declines and that number rises as fields age and more equipment is installed in new fields.

Downstream and domestic demand - The stellar growth in domestic consumption, partly fuelled by government subsidies, has weighed heavily on Petrobras. 2011 was the big turning point, when the government decided to subsidize fuel prices through an unofficial mechanism, accelerating domestic demand growth and resulting in Petrobras having to import products such as gasoline and diesel at international prices. As a result, the downstream segment has made huge losses.

Changes to the regulatory framework - Once the scale of the pre-salt region became clear after the Tupi discovery, intervention by the Brazilian government has substantially slowed progress. Petrobras was given exclusivity in pre-salt basins and areas deemed strategic and as a result international oil companies considering investing in the pre-salt basin may be considered as mere capital donors, without an effective say in important decisions.

While there is little doubt that Brazil will continue to play a key role in global oil market dynamics, it has all gone a bit wrong for a country that only a few years ago saw itself as an oil super power that would help meet the world's oil demand. Given the scale and the nature of challenges facing its oil sector, it is time for Brazil, and the world, to face reality and scale back their 'great expectations' for the nation's oil supply potential. 

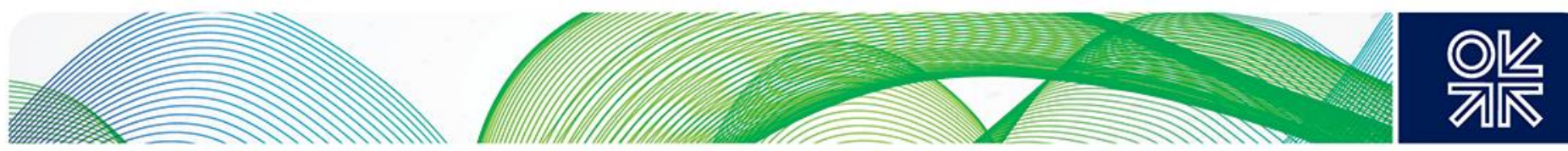

\section{Appendix: Evolution of Petrobras' business plans}

\section{8-2012 Business Plan}

- 2008 production target set at 2.05 million $\mathrm{b} / \mathrm{d}$. Actual production was 1.86 million $\mathrm{b} / \mathrm{d} .{ }^{76}$

- E\&P investments were $\$ 65.1$ billion (revised up from $\$ 49.3$ billion in the 2007-2011 plan).

- The company's overall investment plan totalled $\$ 112$ billion, $\$ 104.4$ billion (93 per cent) of which was expected to be generated from free cash flow.

- Brent was forecast at $\$ 55$ per barrel in $2008, \$ 50$ per barrel in 2009 , $\$ 45$ per barrel in 2010 and an average $\$ 35$ per barrel for 2011 and 2012.

- Company's costs increase $\$ 10.9$ billion due to rising expenses in the service sector.

\section{9-2013 Business Plan}

- 2009 production target set at 2.05 million b/d. Actual production was 1.97 million b/d. ${ }^{77}$

- E\&P spending increased $\$ 39.5$ billion to $\$ 104.6$ billion, of which $\$ 92$ billion would be spent in Brazil.

- Management expected the following pre-salt projects to come on stream towards the end of the forecasting period: Tupi phase 1 (2012), Guara phase 1 (2012), and lara phase 1 (2013).

\section{0-2014 Business Plan}

- 2010 production target set at 2.10 million b/d. Actual production was 2 million $\mathrm{b} / \mathrm{d} .{ }^{78}$

- E\&P investment increased to $\$ 118.8$ billion.

- Petrobras acknowledged that operational cash flow would not be sufficient to meet the $\$ 224$ billion investment plan, and thus would need to raise debt and equity of almost $\$ 100$ billion over the five-year period.

- Petrobras raises $\$ 70$ billion in the world's largest equity offering.

- Financial planning assumptions - Brent prices raised by average $\$ 15$ for forecast period.

\footnotetext{
${ }^{76}$ Petrobras $2008-2012$ business plan

${ }_{77}$ Petrobras 2009-2013 business plan.

${ }^{78}$ Petrobras 2010-2014 business plan.
} 

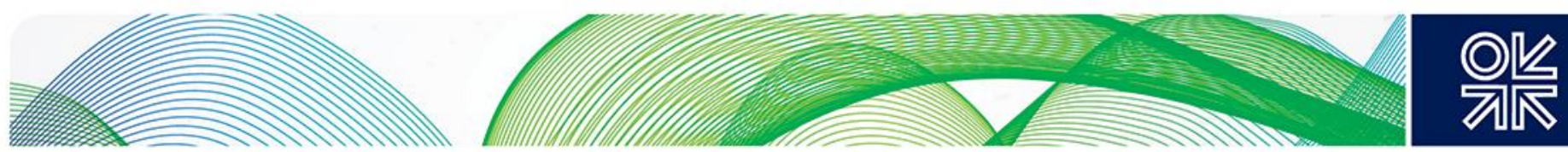

\section{1-2015 Business Plan}

- 2011 production target set at 2.1 million b/d. Actual production was 2.02 million b/d. ${ }^{79}$

- E\&P investments increased to $\$ 128$ billion, higher year-on-year by $\$ 8.7$ billion.

- Divestments / restructuring entered the plan for $1^{\text {st }}$ time, in order to manage debt levels.

- There was a sharp increase in exploration investment outside of the pre-salt, where total annual investments were expected to be in the region of $\$ 4$ billion.

- Financial planning assumptions - Brent prices raised by average $\$ 6$ for forecast period.

- Pre-salt investments had increased above $\$ 50$ billion to $\$ 53.4$ billion, while post-salt investments totalled $\$ 64.3$ billion.

\section{2-2016 Business Plan}

- 2012 production target revised down to just over 2 million b/d. Actual production was 1.98 million $\mathrm{b} / \mathrm{d} .{ }^{80}$

- E\&P spending increased to $\$ 141.8$ billion or 60 per cent of Petrobras' total five-year capex plan. (Brazilian E\&P spend of $\$ 131.6$ billion).

- Acknowledged that for eight consecutive business plans its targets proved to be too aggressive and unrealistic.

- Downstream was cited to highlight project schedule delays and cost over-runs. The Abreu e Lima refinery start has been delayed by three years whilst investment had risen nine-fold, from $\$ 2.3$ billion to $\$ 20.1$ billion.

- New management sets targets based on 'real' projects timescales.

- In August, the company posted its first quarterly loss in 13 years.

- Medium-term production targets were reduced by 1 million b/d along certain parts of the production curve, whilst 2020 output target was reduced by 17 per cent, or 0.71 million b/d, to 4.2 million b/d.

- Financial planning assumptions - Brent price outlook is $\$ 110$ for 2012 and $\$ 90$ in the long term.

- In light of the cost escalation, management introduced capital discipline in addition to managing projects more effectively. A priority would be given to E\&P projects in Brazil.

- Announced a divestment target of $\$ 14.8$ billion for assets outside of Brazil. 

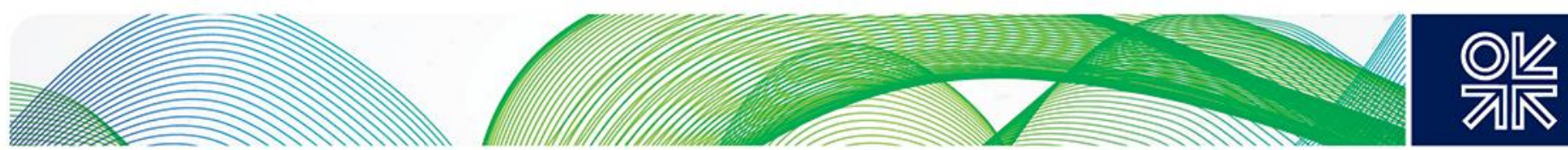

\section{3-2017 Business Plan}

- 2013 production target set at 2 million b/d. Actual production declined year-on-year by 49 thousand b/d. ${ }^{81}$

- E\&P investment rose to $\$ 147.5$ billion or 62.3 per cent of total budget.

- Maintained similar production targets to previous business plan although maintenance and delays impacted output.

- Pre-salt oil production reached 0.3 million b/d (43 per cent from the Santos Basin, 57 per cent from the Campos).

- Forecasts pre-salt output to reach 1 million b/d by 2017 and 2.1 million b/d by 2020.

- Financial planning assumptions - Brent price outlook is $\$ 107$ for 2013 and $\$ 100$ in the long term.

- Reported divestments of $\$ 9.9$ billion and puts focus on maintaining investment grade rating.

\section{4-2018 Business Plan}

- 2014 production target set at 2.08 million b/d. H1 14 data shows output at 1.95 million $\mathrm{b} / \mathrm{d} .{ }^{9}$

- 2013 production was impacted by a number of project delays which delayed $1^{\text {st }}$ oil and ramp up at P-63/Papa Terra, Cidade de São Paulo/Sapinhoá and Cidade de Paraty/Lula NE, P-55 Roncador, P-58 Parque das Baleias.

- E\&P investment reaches $\$ 153.9$ billion (70 per cent of the total plan).

- Of the total E\&P investment, 73 per cent would be allocated to production development, 15 per cent to exploration and 12 per cent to infrastructure.

- In the five-year period, 28 new production units are expected anticipated to start up.

- Pre-salt to account for 60 per cent of the total investment in production development, with post-salt making up the rest.

- In addition to Petrobras' investments, the Brazilian E\&P sector will require another $\$ 44.8$ billion from partners.

- Financial planning assumptions - Brent price outlook is $\$ 105$ for 2014 and $\$ 100$ in long term.

- Debt financing has risen to $\$ 60.5$ billion in the latest plan. 